\title{
Chloride Uptake by Brush Border Membrane Vesicles Isolated from Rabbit Renal Cortex
}

\author{
COUPLING TO PROTON GRADIENTS AND K ${ }^{+}$DIFFUSION POTENTIALS
}

\author{
DAvid G. WARNOCK and Victoria J. YeE, Cardiovascular Research Institute and \\ Department of Medicine, University of California, San Francisco, \\ California 94143
}

\begin{abstract}
A B S T R A C T Brush border membrane vesicles were isolated from rabbit renal cortex by $\mathrm{Mg}^{++}$-precipitation and differential centrifugation. ${ }^{36} \mathrm{Cl}^{-}$and $\left[{ }^{3} \mathrm{H}\right]$ glucose uptakes were simultaneously determined by a rapid filtration technique. Lysis of the vesicles with distilled water abolished $90-95 \%$ of the radioactivity on the filters, suggesting that nearly all of the ${ }^{36} \mathrm{Cl}^{-}$and $\left[{ }^{3} \mathrm{H}\right]-$ glucose counts represented uptake into an osmotically reactive intravesicular space. Inwardly directed $\mathrm{K}^{+}$ gradients plus valinomycin stimulated ${ }^{36} \mathrm{Cl}^{-}$uptake, demonstrating a conductive pathway for chloride uptake into brush-border membrane vesicles. ${ }^{36} \mathrm{Cl}^{-}$ uptake could also be stimulated by inwardly directed proton gradients $\left(\mathrm{pH}_{\text {outside }}<\mathrm{pH}_{\text {inside }}\right)$. This effect was seen in the absence of sodium, as well as in the presence of valinomycin when the vesicles had equal $\mathrm{K}^{+}$ concentrations inside and out. An "overshoot" phenomenon was observed when external ${ }^{36} \mathrm{Cl}^{-}$was $2 \mathrm{mM}$ and the external $\mathrm{pH}$ was lowered from 7.5 to 6.0 or to 4.5. The effect of the proton gradient was presumed to be different from the conductive mechanism because (a) the stimulation of ${ }^{36} \mathrm{Cl}^{-}$uptake by in wardly directed $\mathrm{K}^{+}$diffusion potentials was additive to the proton gradient effect, and $(b)$ competition studies revealed statistically significant effects of thiocyanate on the conductive pathway, but not on the proton-driven pathway.
\end{abstract}

$\mathrm{HCl}$ cotransport or anion exchange are electrically neutral mechanisms which could couple ${ }^{36} \mathrm{Cl}^{-}$uptake to inwardly-directed proton gradients in a brush border

Portions of these results were presented at the 64th Annual Meeting of the Federation of American Societies for Experimental Biology, Anaheim, Calif. (1980. Fed. Proc. 39: 734A), and the XXVIII International Congress of Physiological Sciences, Budapest, Hungary (1980. Proc. Int. Congr. Physiol. Sci. XVIII. In press.).

Received for publication 8 February 1.980 and in revised form 2 September 1980. membrane vesicle. If both electrically neutral and conductive pathways for chloride transport are present in the luminal membrane of the proximal tubule, then the mechanism as well as the direction of net chloride transport will be influenced by the nature of the accompanying cation transport process.

\section{INTRODUCTION}

There are several coupled transport processes in the proximal tubule by which sodium is cotransported with organic solutes across the luminal membrane (1-4). The driving force for these reabsorptive processes, by extrapolation from studies with other tissues, is provided by the electrochemical gradient for sodium between lumen and cell $(5,6)$. Sodium-dependent glucose cotransport has been well characterized by studies of brush border membrane vesicles prepared from the intestine and renal cortex of rat, rabbit, dog, and human kidney (7-17). The rate of glucose accumulation, including a transient "overshoot" phenomenon, depends upon the particular anion that is present during sodium-dependent glucose cotransport $(7,8,11,13,14,17,18)$. These anion effects are the basis for the inference that there is a conductive (i.e., electro-diffusional) pathway for anion transport in parallel with the sodium cotransport mechanisms in brush border membrane vesicles.

Most of the filtered load of bicarbonate and organic solutes is reabsorbed in early segments, while chloride reabsorption predominates in later segments of the proximal tubule (19-25). Hence, there may be chloride transport mechanisms in the late proximal tubule that are fundamentally different from those associated with sodium-coupled organic solute transport in the early proximal tubule. Several investigators (19-25) have proposed that "passive" paracellular transport mechanisms (e.g., diffusion, convection) may contribute 
to the reabsorption of salt and water in the late proximal tubule (19-25). Alternatively, recent studies suggest that transcellular, electrically neutral transport of chloride may occur in the late proximal tubule (26-29). A specific model for neutral $\mathrm{NaCl}$ reabsorption has been proposed for the proximal tubule that incorporates a parallel arrangement of $\mathrm{Na}^{+} / \mathrm{H}^{+}$and $\mathrm{Cl}^{-} / \mathrm{OH}^{-}$ exchange mechanisms in the luminal membrane (29). The presence of an electrically neutral $\mathrm{Na}^{+} / \mathrm{H}^{+}$antiport has been described in brush-border membrane vesicles prepared from the small intestine and the renal cortex (30). Other studies have examined electrically neutral uptake mechanisms for various anions in brush border membrane vesicles prepared from the small intestine (31-33), and renal cortex (34-36). However, specific information about the pathways of chloride transport across the luminal membrane of the proximal tubule is not currently available.

The present paper describes two possible mechanisms for ${ }^{36} \mathrm{Cl}^{-}$uptake in brush border membrane vesicles prepared from rabbit renal cortex. A conductive pathway can be demonstrated by the stimulation of ${ }^{36} \mathrm{Cl}^{-}$uptake with inwardly directed $\mathrm{K}^{+}$gradients plus valinomycin (VAL). ${ }^{136} \mathrm{Cl}^{-}$uptake could also be stimulated by inwardly directed proton gradients $\left(\mathrm{pH}_{\mathrm{o}}\right.$ [outside] $<\mathrm{pH}_{\mathrm{i}}$ [inside]). Both ${ }^{36} \mathrm{Cl}^{-}$uptake processes can be demonstrated in the complete absence of sodium, and are therefore not coupled to sodium transport in an obligatory fashion. However, if these chloride transport pathways are functional in the in vivo tubule, then chloride transport could be indirectly coupled to sodium transport across the luminal membrane by $(a)$ the lumen-negative electrical potential difference (PD), and depolarization of the luminal membrane associated with electrogenic sodium transport (e.g., glucose cotransport), or $(b)$ by $\mathrm{pH}$ gradients generated across the luminal membrane by $\mathrm{Na}^{+} / \mathrm{H}^{+}$exchange. Hence, the nature of the sodium transport mechanism may determine the mode of chloride transport across the luminal membrane of the proximal tubule. Electrodiffusional chloride transport may accompany electrogenic sodium transport in early segments of the proximal tubule, while chloride transport that is coupled to the proton gradient may predominate in the late proximal tubule once the filtered loads of organic solutes and bicarbonate have been reabsorbed.

\section{METHODS}

Membrane preparation. Female New Zealand white rabbits, $2-3 \mathrm{~kg}$ in weight, were killed by decapitation. Each kidney was perfused via the renal artery with $35 \mathrm{ml}$ of ice-cold

${ }^{1}$ Abbreviations used in this paper: i, inside; Mes 2-(NMorpholino) ethanesulfonic acid; o, outside; PD, electrical potential difference; $\mathrm{TMA}^{+}$, tetramethyl-ammonium; VAL, valinomycin. homogenizing solution: $50 \mathrm{mM}$ mannitol, $2 \mathrm{mM}$ Tris/ $\mathrm{HCl}$ (pH 7.0), and $0.5 \mathrm{mM}$ EDTA. The kidneys of two rabbits were removed, and the cortical tissue was homogenized in $330 \mathrm{ml}$ of homogenizing solution with an Omni-Mixer (Sorvall, Du Pont Instruments-Du Pont Co., Newtown, Conn.) for $4 \mathrm{~min}$. Brush border membrane fractions were then prepared by precipitation with $12 \mathrm{mM} \mathrm{MgSO}_{4}$ and differential centrifugation $(13,15,17,37-39)$. Subsequent homogenizations and centrifugations were usually done in a solution containing $100 \mathrm{mM}$ mannitol, $1 \mathrm{mM}$ Hepes/Tris

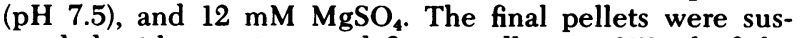
pended with a syringe and fine needle in $\sim 250 \mu \mathrm{l}$ of the appropriate buffer (indicated in text) for at least an hour ("preloading") before the uptake studies.

The purity of the membrane fractions was determined by enzyme assays. The methods and results were quite similar to previous reports $(13,14,17,33,37-42)$. The enrichment of the brush border marker, alkaline phosphatase, was 10 fold (10 separate determinations), and the enrichment of the baso-lateral marker, $\mathrm{K}^{+}$-stimulated phosphatase, was 0.4 (10 separate determinations).

Uptake studies. Solute uptake was assayed by a rapid filtration technique (43). The usual composition of the final incubation media was $40 \mathrm{mM} \mathrm{K} \mathrm{SO}_{4}, 20 \mathrm{mM} \mathrm{Na}{ }^{36} \mathrm{Cl}$ or $20 \mathrm{mM}$ tetramethyl-ammonium (TMA) ${ }^{36} \mathrm{Cl}(9.5 \mu \mathrm{Ci} / \mathrm{ml}), 0.14$ $\mathrm{mM}$ D- $\left[{ }^{3} \mathrm{H}\right]$ glucose $(22 \mu \mathrm{Ci} / \mathrm{ml})$, and $50 \mathrm{mM}$ Hepes/Tris ( $\mathrm{pH}$ 7.5). The concentration of mannitol was adjusted so that the buffer solutions were isoosmotic. The $\mathrm{pH}$ of incubation media and vesicle preparations was checked with a combination $\mathrm{pH} / \mathrm{reference}$ electrode (model MI-410; Microelectrodes, Inc., Londonderry, N. H.). The pH was adjusted to the indicated values with Tris base or $\mathrm{H}_{2} \mathrm{SO}_{4}$. Changes in the composition of the incubation media as well as the stop solutions are indicated in the text, figure legends, and in the tables. The stop solution contained $60 \mathrm{mM} \mathrm{MgSO}_{4}, 40 \mathrm{mM}$ $\mathrm{K}_{2} \mathrm{SO}_{4}, 150 \mathrm{mM}$ mannitol, $1.0 \mathrm{mM}$ glucose, $0.4 \mu \mathrm{Ci} / \mathrm{ml}$ of $\left[{ }^{14} \mathrm{C}\right]$ glucose, and $0.2 \mathrm{mM}$ phloridzin. Identical results were obtained if the salts in the stop solution were $100 \mathrm{mM}$ $\mathrm{K}_{2} \mathrm{SO}_{4}$ or $100 \mathrm{mM}$ potassium gluconate. Cellulose nitrate filters $(0.65-\mu \mathrm{m}$ pore size; Beckman Instruments, Inc., Palo Alto, Calif.) were used for the uptake assays. Usually $30 \mu \mathrm{l}$ of the membrane suspension was added to $140 \mu$ l of incubation media at "zero" time, and then kept in a thermal block at $25^{\circ} \mathrm{C}$. VAL, or ethanol was added to the membrane suspension before the addition of the incubation media. At different time intervals $(0.15,0.5,1,2$, and $6 \mathrm{~min})$, a $20-\mu \mathrm{l}$ sample was removed from the incubation suspension and diluted into $1 \mathrm{ml}$ of ice-cold stop solution and immediately filtered. The filters were then washed with $5 \mathrm{ml}$ of ice-cold wash solution to remove extravesicular radioactivity. Three samples were assayed at 60 or $120 \mathrm{~min}$ to determine the uptake counts at equilibrium. The wash solution was identical to the stop solution except that $\left[{ }^{14} \mathrm{C}\right]$ glucose was omitted. The radioactivity on the filters was counted with standard triple-label liquid-scintillation techniques (44). The percent "spill" was determined with isotopic standards (average of five determinations): ${ }^{3} \mathrm{H}$ into the ${ }^{14} \mathrm{C}$ channel, $0.026 \pm 0.004 \%$; ${ }^{3} \mathrm{H}$ into the ${ }^{36} \mathrm{Cl}^{-}$channel, $0.000 \%$; ${ }^{14} \mathrm{C}$ into the ${ }^{3} \mathrm{H}$ channel, $28.1 \pm 0.3 \%$; ${ }^{14} \mathrm{C}$ into the ${ }^{36} \mathrm{Cl}^{-}$channel, $0.17 \pm 0.01 \% ;{ }^{36} \mathrm{Cl}^{-}$ into the ${ }^{3} \mathrm{H}$ channel, $3.6 \pm 0.1 \%$; and ${ }^{36} \mathrm{Cl}^{-}$into the ${ }^{14} \mathrm{C}$ channel, $46.1 \pm 1.4 \%$. These coefficients were used to solve three simultaneous equations to obtain the spill-corrected ${ }^{3} \mathrm{H},{ }^{14} \mathrm{C}$, and ${ }^{36} \mathrm{Cl}^{-}$counts for each sample. The ${ }^{14} \mathrm{C}$ counts on each filter originated in the iced-stop solution, and were used to correct the ${ }^{3} \mathrm{H}$ solute and ${ }^{36} \mathrm{Cl}^{-}$counts for extravesicular radioactivity. Aliquots of each of the final incubation mixtures were counted for determining the specific activities of ${ }^{3} \mathrm{H}$ solute and ${ }^{36} \mathrm{Cl}^{-}$. The protein concentration of each of the 
final incubation mixtures was measured with the Folin phenol reagent (45), using bovine serum albumin as a standard, and ranged between 7 and $10 \mathrm{mg} / \mathrm{ml}$.

Statistics and materials. Uptake results were expressed as nanomoles per milligram protein, mean \pm SEM. Statistical comparisons were done with paired, two-tailed $t$ tests. $P$ values $>0.05$ were considered to be nonsignificant. $P$ values $\leq 0.05$ are indicated by $\left({ }^{*}\right)$ in the figures.

All chemicals were of the highest purity available. VAL and cellobiose were purchased from Sigma Chemical Co. (St. Louis, Mo.), phloridzin from ICN K \& K Laboratories, Inc. (Plainview, N. Y.), and L-glucose from Calbiochem Behring Corp., American Hoechst Corp. (La Jolla, Calif.). D- and $L-\left[{ }^{3} \mathrm{H}\right]$ glucose were purchased from New England Nuclear (Boston, Mass.). $\left[{ }^{14} \mathrm{C}\right]$ glucose, $\mathrm{Na}^{36} \mathrm{Cl}, \mathrm{H}^{36} \mathrm{Cl}$, and TMA ${ }^{36} \mathrm{Cl}$ were purchased from ICN, Pharmaceuticals Inc., Irvine, Calif.

\section{RESULTS}

Uptake of $\mathrm{D}-\left[{ }^{3} \mathrm{H}\right]$ glucose and ${ }^{36} \mathrm{Cl}^{-}$in the presence of $\mathrm{Na}^{+}$. The uptakes of $\mathrm{D}-\left[{ }^{3} \mathrm{H}\right]$ glucose and ${ }^{36} \mathrm{Cl}^{-}$are presented in Fig. 1. The D- $\left[{ }^{3} \mathrm{H}\right]$ glucose uptake $(\mathrm{O}$, Fig. 1) shows a typical "overshoot", and reaches a final equilibrium value of $0.13 \pm 0.01 \quad(n=6) \mathrm{nmol} / \mathrm{mg}$ protein at $60 \mathrm{~min} .{ }^{36} \mathrm{Cl}^{-}$uptake values are shown in the lower panel $(O)$, and averaged $15.8 \pm 0.8(n=6) \mathrm{nmol} /$ $\mathrm{mg}$ protein at $60 \mathrm{~min}$. The effect of a transmembrane PD on ${ }^{36} \mathrm{Cl}^{-}$uptake was examined by imposing an inwardly directed $\mathrm{K}^{+}$gradient $\left(\left[\mathrm{K}^{+}\right]_{\mathrm{o}}>\left[\mathrm{K}^{+}\right]_{\mathrm{i}}\right)$. The membrane $\mathrm{K}^{+}$

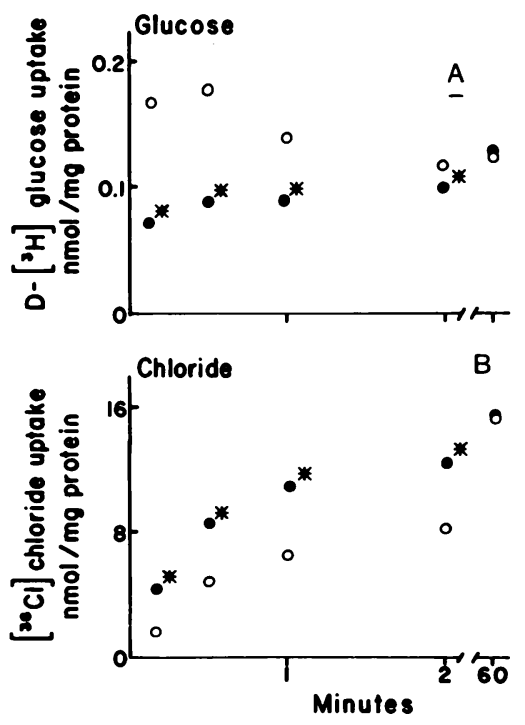

FigURE 1 Uptake of $\mathrm{D}-\left[{ }^{3} \mathrm{H}\right]$ glucose (A) and ${ }^{36} \mathrm{Cl}^{-}$(B) by brush border membrane vesicles: effect of inwardly directed $\mathrm{K}^{+}$gradient $\left(\left[\mathrm{K}^{+}\right]_{0}>\left[\mathrm{K}^{+}\right]_{\mathrm{i}}\right)$ in the presence of $\mathrm{Na}^{+}$. Vesicles were preloaded with $100 \mathrm{mM}$ mannitol, $10 \mathrm{mM} \mathrm{MgSO}_{4}$, and $1 \mathrm{mM}$ Hepes/Tris $\left(\mathrm{pH}_{1}=7.5\right)$. External incubation medium contained $40 \mathrm{mM} \mathrm{K} \mathrm{SO}_{4}, 20 \mathrm{mM} \mathrm{Na}{ }^{36} \mathrm{Cl}, 0.14 \mathrm{mM} \mathrm{D}-\left[{ }^{3} \mathrm{H}\right]-$ glucose, and $1 \mathrm{mM}$ Hepes/Tris $\left(\mathrm{pH}_{\mathrm{o}}=7.5\right)$. $\bigcirc$, control series; , plus VAL $(100 \mu \mathrm{g} / \mathrm{ml})$. Starred values $\left(^{*}\right)$ are significantly different from the control series $(P \leq 0.05 ; n=5$ paired studies). conductance is increased by VAL $(46,47)$, and a $\mathrm{K}^{+}$ diffusion PD (interior-positive) is created. The inwardly directed $\mathrm{K}^{+}$gradient was achieved by preloading the vesicles with $40 \mathrm{mM} \mathrm{MgSO}_{4}$, and incubating them in an external medium containing $40 \mathrm{mM} \mathrm{K}_{2} \mathrm{SO}_{4}$. The effect of the $\mathrm{K}^{+}$diffusion potential (plus VAL) on D$\left[{ }^{3} \mathrm{H}\right]$ glucose uptake is shown by the closed circles in the upper panel of Fig. 1. The overshoot was abolished, but the final equilibrium value for $\mathrm{D}-\left[{ }^{3} \mathrm{H}\right]$ glucose was the same as the control series. In contrast, ${ }^{36} \mathrm{Cl}^{-}$uptake was significantly increased at the earlier time points without any effect on the 60 -min equilibrium value $(\bullet$, Fig. 1B). The effects of a $\mathrm{K}^{+}$gradient plus VAL on D$\left[{ }^{3} \mathrm{H}\right]$ glucose uptake are consistent with generation on an interior-positive PD and consequent inhibition of electrogenic sodium-coupled glucose cotransport (7-18). Stimulation of ${ }^{36} \mathrm{Cl}^{-}$uptake by the inwardly directed $\mathrm{K}^{+}$ diffusion PD demonstrates the conductive (i.e., electrodiffusional) pathway for chloride entry. A conductive pathway for chloride entry has been inferred from previous studies of brush border membrane vesicles (7-17), and has also been demonstrated in mitochondria $(48,49)$.

Uptake of $\mathrm{D}-\left[{ }^{3} \mathrm{H}\right] \mathrm{glucose}$ and ${ }^{36} \mathrm{Cl}^{-}$in the absence of $\mathrm{Na}^{+}$. The presence of $\mathrm{Na}^{+}$complicates the analysis of ${ }^{36} \mathrm{Cl}^{-}$uptake because of the variety of uptake processes in which $\mathrm{Na}^{+}$may participate (i.e., glucose-coupled cotransport (7-18), possible conductive entry of $\mathrm{Na}^{+}$ $[30,50]$, neutral, coupled entry with chloride [28, 51-57], and $\mathrm{Na}^{+} / \mathrm{H}^{+}$exchange $\left.[30,58]\right)$. Therefore, to simplify the study of ${ }^{36} \mathrm{Cl}^{-}$uptake, $\mathrm{Na}^{+}$was replaced by another cation, $\mathrm{TMA}^{+}$, which we assume to be impermeant $(28,55)$. The studies in Fig. 2 examined the effect of sodium removal upon the conductive entry of ${ }^{36} \mathrm{Cl}^{-}$. The vesicles were preloaded with 40 $\mathrm{mM} \mathrm{MgSO}_{4}$, and the external incubation media contained $40 \mathrm{mM} \mathrm{K}_{2} \mathrm{SO}_{4}$. In the absence of $\mathrm{Na}^{+}$, the uptake of $\mathrm{D}-\left[{ }^{3} \mathrm{H}\right]$ glucose at equilibrium is an indication of intravesicular volume $(7-18)$. The control values $(O$, Fig. 2) were obtained without VAL. The addition of $\operatorname{VAL}\left(\bullet\right.$, Fig. 2) increased ${ }^{36} \mathrm{Cl}^{-}$uptake, but had no effect upon $\mathrm{D}-\left[{ }^{3} \mathrm{H}\right]$ glucose entry or on the equilibrium values for $\mathrm{D}-\left[{ }^{3} \mathrm{H}\right]$ glucose or ${ }^{36} \mathrm{Cl}^{-}$. These results show that conductive uptake of ${ }^{36} \mathrm{Cl}^{-}$can be driven by a $\mathrm{K}^{+}$diffusion PD (inwardly-directed $\mathrm{K}^{+}$gradient plus VAL), even in the absence of $\mathrm{Na}^{+}(\boldsymbol{O}$, Fig. 2B).

An inwardly directed chloride gradient $\left(\left[\mathrm{Cl}^{-}\right]_{0}\right.$ $\left.>\left[\mathrm{Cl}^{-}\right]_{\mathrm{i}}\right)$ may generate an interior-negative diffusion PD via the conductive pathway for chloride entry. Depending on the magnitude of the chloride diffusion $\mathrm{PD}$, adding VAL with equal $\mathrm{K}^{+}$concentrations inside and out $\left(\left[\mathrm{K}^{+}\right]_{\mathrm{o}}=\left[\mathrm{K}^{+}\right]_{\mathrm{i}}\right)$ may enhance ${ }^{36} \mathrm{Cl}^{-}$uptake by allowing parallel, compensating charge movement of $\mathrm{K}^{+}$through the VAL pathway. Fig. 3 shows the results when vesicles were preloaded with $40 \mathrm{mM}$ $\mathrm{K}_{2} \mathrm{SO}_{4}, 100 \mathrm{mM}$ mannitol, and $50 \mathrm{mM}$ Hepes/Tris 


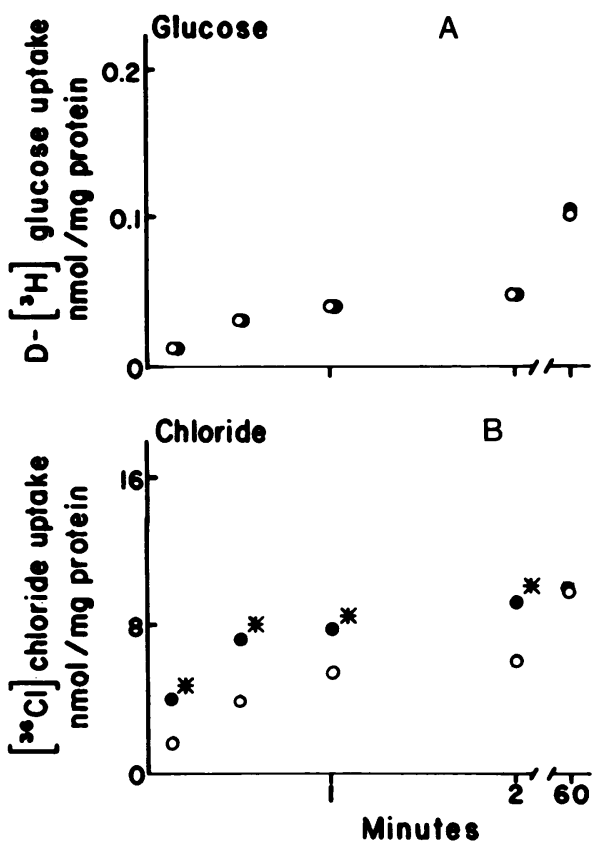

Figure 2 Uptake of $\mathrm{D}-\left[{ }^{3} \mathrm{H}\right]$ glucose (A) and ${ }^{36} \mathrm{Cl}^{-}$(B) by brush border membrane vesicles: effect of inwardly directed $\mathrm{K}^{+}$ gradient $\left(\left[\mathrm{K}^{+}\right]_{0}>\left[\mathrm{K}^{+}\right]_{\mathbf{i}}\right)$ in the absence of $\mathrm{Na}^{+}$. Vesicles were preloaded with $40 \mathrm{mM} \mathrm{MgSO}, 100 \mathrm{mM}$ mannitol, and $50 \mathrm{mM}$ Hepes/Tris $\left(\mathrm{pH}_{\mathrm{i}}=7.5\right)$. External incubation media contained $40 \mathrm{mM} \mathrm{K}_{2} \mathrm{SO}_{4}, 20 \mathrm{mM} \mathrm{TMA}{ }^{36} \mathrm{Cl}, 0.14 \mathrm{mM} \mathrm{D}-\left[{ }^{3} \mathrm{H}\right]-$ glucose, and $50 \mathrm{mM}$ Hepes/Tris $\left(\mathrm{pH}_{\mathrm{o}}=7.5\right)$. $\bigcirc$, control series; , plus VAL $(100 \mu \mathrm{g} / \mathrm{ml})$. Starred values $\left({ }^{*}\right)$ are significantly different from the control series $(P \leq 0.5 ; n=9$ paired studies)

( $\mathrm{pH}$ 7.5). The buffer content, $\mathrm{pH}$ and $\mathrm{K}_{2} \mathrm{SO}_{4}$ concentration of the external incubation media were identical so that there was no transmembrane $\mathrm{K}^{+}$gradient. The control uptake values (minus VAL) are shown as open circles in Fig. 3. The addition of VAL had no effect

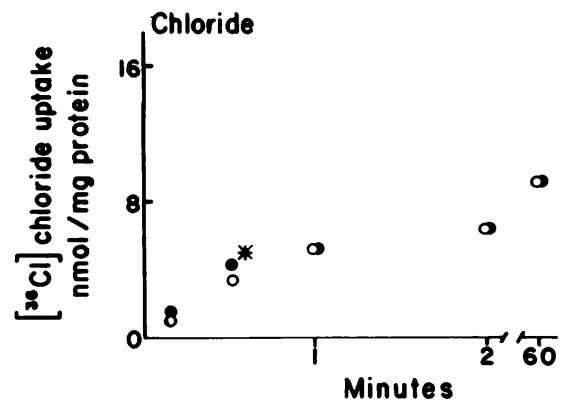

Figure 3 Uptake of ${ }^{36} \mathrm{Cl}^{-}$by brush border membrane vesicles: effect of zero $\mathrm{K}^{+}$gradient $\left(\left[\mathrm{K}^{+}\right]_{i}=\left[\mathrm{K}^{+}\right]_{0}\right)$ in the absence of $\mathrm{Na}^{+}$. Vesicles were preloaded with $40 \mathrm{mM}$ $\mathrm{K}_{2} \mathrm{SO}_{4}, 100 \mathrm{mM}$ mannitol, and $50 \mathrm{mM}$ Hepes/Tris $\left(\mathrm{pH}_{4}\right.$ $=7.5$ ). External incubation medium contained $40 \mathrm{mM}$ $\mathrm{K}_{2} \mathrm{SO}_{4}, 20 \mathrm{mM} \mathrm{TMA}^{36} \mathrm{Cl}, 0.14 \mathrm{mM} \mathrm{D}-\left[^{3} \mathrm{H}\right] \mathrm{glucose}$, and 50 $\mathrm{mM}$ Hepes/Tris $\left(\mathrm{pH}_{\mathrm{o}}=7.5\right)$. $\bigcirc$, control series; $\bullet$, plus VAL $(100 \mu \mathrm{g} / \mathrm{ml})$. Starred value $(*)$ is significantly different from the control series ( $P \leq 0.05 ; n=5$ paired studies). on the uptake of $\mathrm{D}-\left[{ }^{3} \mathrm{H}\right]$ glucose (data not shown). A slight increase of ${ }^{36} \mathrm{Cl}^{-}$uptake was observed with VAL at $0.5 \mathrm{~min}(3.6 \pm 0.4 \mathrm{vs} .4 .4 \pm 0.4 \mathrm{nmol} / \mathrm{mg})$, which was statistically significant $(P \leq 0.001, n=5$ paired studies). VAL did not affect ${ }^{36} \mathrm{Cl}^{-}$uptake at any of the other time points (๑, Fig. 3). The slight stimulation of ${ }^{36} \mathrm{Cl}^{-}$uptake at $0.5 \mathrm{~min}$ probably represents conductive entry of ${ }^{36} \mathrm{Cl}^{-}$accompanied by a parallel movement of $\mathrm{K}^{+}$ through the VAL pathway: $\mathrm{K}^{+}$entry driven by the inwardly directed ${ }^{36} \mathrm{Cl}^{-}$gradient.

Stimulation of ${ }^{36} \mathrm{Cl}^{-}$uptake by $p \mathrm{H}$ gradients. Murer, Hopfer, and Kinne (30) found an electrically neutral exchanger (antiport) for $\mathrm{Na}^{+} / \mathrm{H}^{+}$in brush border membrane vesicles from rat intestine and kidney cortex (30). One feature of the $\mathrm{Na}^{+} / \mathrm{H}^{+}$antiport was the counterflow phenomena; ${ }^{22} \mathrm{Na}^{+}$entry could be stimulated by an outwardly directed proton gradient $\left(\mathrm{pH}_{\mathrm{i}}\right.$ $<\mathrm{pH}_{\mathrm{o}}$ ) (30). If the vesicle membrane also contains $\mathrm{Cl}^{-} / \mathrm{OH}^{-}$exchangers or $\mathrm{HCl}$ cotransport systems, then a similar counterflow phenomena should be observed: ${ }^{36} \mathrm{Cl}^{-}$uptake driven by an inwardly directed proton gradient $\left(\mathrm{pH}_{0}<\mathrm{pH}_{\mathrm{i}}\right)$.

The same buffer systems described by Murer et al. (30) were used to examine the effects of proton gradients on ${ }^{36} \mathrm{Cl}^{-}$uptake. $\mathrm{L}-\left[{ }^{3} \mathrm{H}\right]$ glucose, rather than $D-\left[{ }^{3} \mathrm{H}\right]$ glucose, was used as the marker for intravesicular volume to avoid the possibility that D-glucose binding may vary with external $\mathrm{pH}$ (59). The vesicles were preloaded with $180 \mathrm{mM}$ mannitol, $1 \mathrm{mM}$ Hepes/ Tris (pH 7.5) buffer, and $40 \mathrm{mM} \mathrm{K}_{2} \mathrm{SO}_{4}$. The external media contained $40 \mathrm{mM}$ mannitol, $40 \mathrm{mM} \mathrm{K}_{2} \mathrm{So}_{4}$, $20 \mathrm{mM} \mathrm{TMA}{ }^{36} \mathrm{Cl}, 0.14 \mathrm{mM} \mathrm{L}-\left[{ }^{3} \mathrm{H}\right]$ glucose, and either $50 \mathrm{mM}$ Hepes/30 mM Tris (pH 7.5) buffer, or $50 \mathrm{mM}$ 2 -(N-Morpholino)ethanesulfonic acid (Mes)/15 mM Tris ( $\mathrm{pH}$ 6.0) buffer. Mannitol was added to each buffer stock so that their osmolalities were 100 mosmol; the total mannitol concentration in the external incubation mixtures was $60 \mathrm{mM}(40+20 \mathrm{mM})$ when $\mathrm{pH}_{\mathrm{o}}=7.5$, and $75 \mathrm{mM}(40+35 \mathrm{mM})$ when $\mathrm{pH}_{\mathrm{o}}=6.0$.

The results are presented in Fig. 4. The control series $\left(\mathrm{pH}_{\mathrm{i}}=\mathrm{pH}_{\mathrm{o}}=7.5\right)$ is represented by open circles. The open squares in Fig. 4B show a significant stimulation of ${ }^{36} \mathrm{Cl}^{-}$uptake by an inwardly directed proton gradient $\left(\mathrm{pH}_{\mathrm{o}}<\mathrm{pH} \mathrm{H}_{\mathrm{i}}\right) . \mathrm{L}-\left[{ }^{3} \mathrm{H}\right]$ glucose uptake, reflecting the intravesicular volume, was also increased with the inwardly directed proton gradient ( $\square$, Fig. 4A). These results are presented as Series $A$ and $B$ in Table $I$. $\mathrm{L}-\left[{ }^{3} \mathrm{H}\right]$ glucose uptake was significantly increased at each time point after $0.5 \mathrm{~min}$ when $\mathrm{pH}_{\mathrm{o}}=6.0$.

The increased ${ }^{36} \mathrm{Cl}^{-}$uptake seen when $\mathrm{pH}_{\mathrm{o}}=6.0$ may be explained by some nonspecific effect which increased intravesicular volume $\left(\mathrm{L}-\left[{ }^{3} \mathrm{H}\right]\right.$ glucose uptake at equilibrium). Cellobiose, an impermeant triose (59) was added to the external incubation media in the next series of studies to eliminate the volume increase; $30 \mathrm{mM}$ cellobiose prevented the increase 


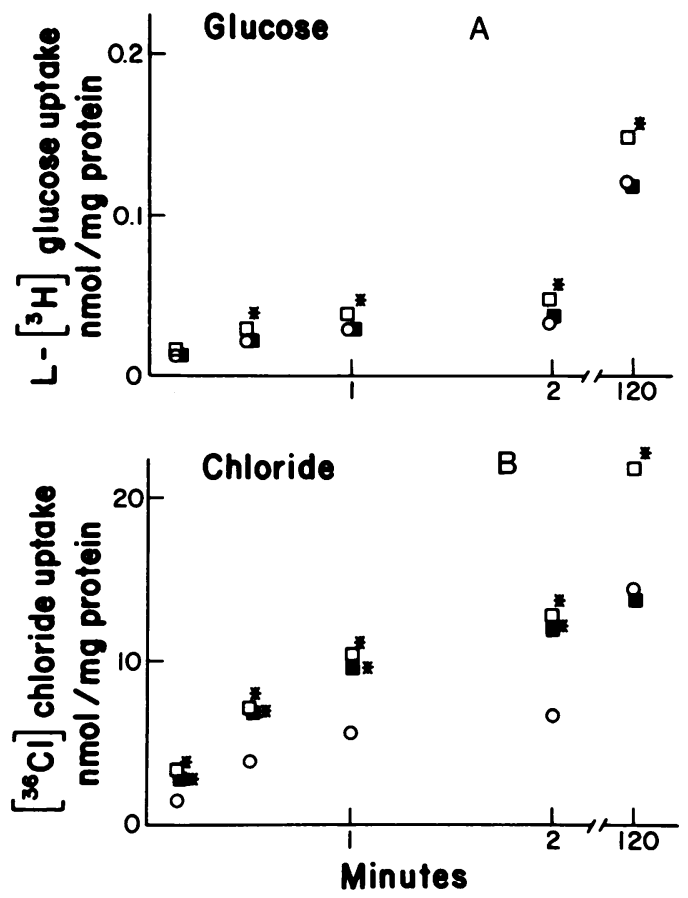

Figure 4 Uptake of $\mathrm{L}_{-}\left[{ }^{3} \mathrm{H}\right] \mathrm{glucose}(\mathrm{A})$ and ${ }^{36} \mathrm{Cl}^{-}$(B) by brush border membrane vesicles: effect of inwardly directed proton gradients $\left(\mathrm{pH}_{\mathrm{o}}<\mathrm{pH}_{\mathrm{i}}\right)$, and cellobiose. Vesicles were preloaded with $40 \mathrm{mM} \mathrm{K}_{2} \mathrm{SO}_{4}, 180 \mathrm{mM}$ mannitol, and $1 \mathrm{mM}$ Hepes/Tris buffer $\left(\mathrm{pH}_{1}=7.5\right)$. External incubation media contained $40 \mathrm{mM} \mathrm{K}_{2} \mathrm{SO}_{4}, 20 \mathrm{mM} \mathrm{TMA}^{36} \mathrm{Cl}, 0.14 \mathrm{mM} \mathrm{L}-\left[{ }^{3} \mathrm{H}\right]-$ glucose, $40 \mathrm{mM}$ mannitol, and $50 \mathrm{mM}$ Hepes/Tris $\left(\mathrm{pH}_{\mathrm{o}}\right.$ $=7.5$ ) in the control series $(O)$. The external buffer was changed to $50 \mathrm{mM}$ Mes/Tris $\left(\mathrm{pH}_{\mathrm{o}}=6.0\right)$ in the series denoted by ( $\square)$, or $50 \mathrm{mM} \mathrm{Mes/Tris}\left(\mathrm{pH}_{\mathrm{o}}=6.0\right)+30 \mathrm{mM}$ cellobiose in the series denoted by $(\square)$. Starred values $\left({ }^{*}\right)$ are significantly different from the control series $(P \leq 0.05 ; n=4$ paired studies).

in intravesicular volume when $\mathrm{pH}_{0}=6.0$. These results are shown as Series $C$ in Table $I$, and as closed squares in Fig. 4. The $\mathrm{L}_{\mathrm{L}}\left[{ }^{3} \mathrm{H}\right]$ glucose uptake values at each time point were not statistically different from the control series (compare Series C to A, Table I, and closed squares to open circles in upper panel, Fig. 4). Thus, the stimulation of ${ }^{36} \mathrm{Cl}^{-}$uptake by the inwardly directed proton gradient $\left(\mathrm{pH}_{\mathrm{o}}=6.0\right)$ was still observed when the intravesicular volume was controlled by the addition of $30 \mathrm{mM}$ cellobiose to the external incubation media (compare series A and C, Table I, and closed squares to open circles, Fig. 4B). The 120min equilibrium values for $\mathrm{L}-\left[{ }^{3} \mathrm{H}\right]$ glucose and ${ }^{36} \mathrm{Cl}^{-}$ uptake were identical for series $\mathrm{A}\left(\mathrm{pH}_{\mathrm{o}}=7.5\right)$ and series $\mathrm{C}\left(\mathrm{pH}_{\mathrm{o}}=6.0\right.$ plus $30 \mathrm{mM}$ cellobiose), and the rate of $\mathrm{L}_{-}\left[{ }^{3} \mathrm{H}\right]$ glucose permeation was unaffected by external $\mathrm{pH}$ when the final equilibrium values were the same (compare series A and C, Table I). These studies demonstrate an effect of external $\mathrm{pH}$ upon ${ }^{36} \mathrm{Cl}^{-}$up- take that can be dissociated from any change in intravesicular volume.

The last series in Table I (series D) examined the effects of VAL on ${ }^{36} \mathrm{Cl}^{-}$uptake. Because the internal and external $\mathrm{K}^{+}$concentrations were identical, the addition of VAL should have minimized any change in transmembrane PD due to the inwardly directed proton gradient by providing a parallel pathway for compensating charge movement. Addition of VAL (series D, Table I) has no effect on the stimulation of ${ }^{36} \mathrm{Cl}^{-}$ uptake by the inwardly directed proton gradient. These results are consistent with, but do not prove, the thesis that stimulation of ${ }^{36} \mathrm{Cl}^{-}$uptake by inwardly directed proton gradient represents an electrically neutral mechanism.

It is important to determine if the results in Fig. 4 and Table I represent uptake of isotope into osmotically reactive intravesicular spaces rather than nonspecific membrane binding. Distilled water was substituted for the usual stop solution in a separate set of equilibrium assays for three of the control studies (series $\mathrm{A}$ and C, Table I, and Fig. 4). This maneuver has been used in previous studies to distinguish between uptake and nonspecific binding $(33,40)$; vesicles burst in distilled water and lose their internal contents. The results are shown in Table II, and compare the equilibrium uptake values that were obtained with the usual stop solutions to those obtained with distilled water stop solutions. Nearly all of the counts were lost when the intravesicular space was abolished by lysis in distilled water. Therefore, $87-90 \%$ of the $\mathrm{L}-\left[{ }^{3} \mathrm{H}\right]$ glucose counts and $95 \%$ of the ${ }^{36} \mathrm{Cl}^{-}$counts in the control series represent uptake of solute into osmotically reactive intravesicular spaces. The residual counts presumably represent binding of isotope to the ruptured membranes or the filters. External pH has no effect on the counts remaining after hypotonic lysis (Table II). Similar results were obtained by treating vesicles with $0.5 \%$ Triton-X 100 (data not shown).

Simulation of ${ }^{36} \mathrm{Cl}^{-}$uptake by $\mathrm{pH}$ gradients: overshoot phenomena. The next series of studies were designed to distinguish between an effect of acid external $\mathrm{pH}$ per se, and the effects of proton gradients on ${ }^{36} \mathrm{Cl}^{-}$uptake. The $\mathrm{pH}$ of the vesicles and incubation media was adjusted to the indicated values by additions of $\mathrm{H}_{2} \mathrm{SO}_{4}$ followed by preincubation for $1 \mathrm{~h}$ before the uptake studies were begun. A single buffer system (50 mM Hepes/30 mM Tris) was used, and the ${ }^{36} \mathrm{Cl}^{-}$in the external incubation media was reduced to $2 \mathrm{mM}$ to increase the relative magnitude of stimulation (32).

The effects of inwardly directed proton gradients upon ${ }^{36} \mathrm{Cl}^{-}$uptake are shown in Fig. 5. (Note that the ordinal scale differs from that in Figs. 1-4.) The vesicles were preloaded with $10 \mathrm{mM}$ Hepes/Tris (pH 7.5) buffer, $100 \mathrm{mM}$ mannitol, and $2 \mathrm{mM} \mathrm{K}_{2} \mathrm{SO}_{4}$. 
TABLE I

Effects of pH Gradients, Cellobiose, and VAL on L- $\left[{ }^{3} \mathrm{H}\right]$ Glucose and ${ }^{36} \mathrm{Cl}-$ Uptake by Renal Brush Border Vesicles

\begin{tabular}{|c|c|c|c|c|c|c|c|c|c|c|}
\hline \multirow[b]{2}{*}{ External condition } & \multicolumn{5}{|c|}{ L- $\left[{ }^{3} \mathrm{H}\right]$ glucose uptake ( $\mathrm{nmol} / \mathrm{mg}$ ) } & \multicolumn{5}{|c|}{${ }^{36} \mathrm{Cl}^{-}$uptake (nmol/mg) } \\
\hline & $0.15 \mathrm{~min}$ & $0.5 \mathrm{~min}$ & $1.0 \mathrm{~min}$ & $2.0 \mathrm{~min}$ & $120 \mathrm{~min}$ & $0.15 \mathrm{~min}$ & $0.5 \mathrm{~min}$ & $1.0 \mathrm{~min}$ & $2.0 \mathrm{~min}$ & $120 \mathrm{~min}$ \\
\hline \multicolumn{11}{|l|}{ A } \\
\hline \multirow[t]{2}{*}{7.5} & 0.010 & 0.021 & 0.028 & 0.032 & 0.119 & 1.3 & 3.8 & 5.6 & 6.8 & 14.4 \\
\hline & \pm 0.002 & \pm 0.002 & \pm 0.003 & \pm 0.003 & \pm 0.007 & \pm 0.4 & \pm 0.4 & \pm 0.6 & \pm 0.7 & \pm 0.9 \\
\hline \multicolumn{11}{|l|}{ B } \\
\hline \multirow[t]{2}{*}{6.0} & 0.015 & 0.031 & 0.037 & 0.045 & 0.146 & 3.5 & 7.0 & 10.4 & 13.0 & 20.9 \\
\hline & \pm 0.002 & \pm 0.002 & \pm 0.003 & \pm 0.005 & \pm 0.008 & \pm 0.2 & \pm 1.6 & \pm 1.7 & \pm 1.7 & \pm 2.3 \\
\hline \multicolumn{11}{|l|}{$\mathrm{C}$} \\
\hline 6.0 & 0.011 & 0.023 & 0.029 & 0.036 & 0.111 & 3.0 & 7.2 & 9.9 & 12.0 & 13.7 \\
\hline+ Cellobiose & \pm 0.002 & \pm 0.001 & \pm 0.001 & \pm 0.003 & \pm 0.008 & \pm 0.2 & \pm 0.3 & \pm 0.4 & \pm 1.2 & \pm 1.2 \\
\hline \multicolumn{11}{|l|}{ D } \\
\hline 6.0 & 0.013 & 0.028 & 0.032 & 0.038 & 0.123 & 3.6 & 6.8 & 9.7 & 11.6 & 13.9 \\
\hline $\begin{array}{l}+ \text { Cellobiose } \\
+ \text { VAL }\end{array}$ & \pm 0.001 & \pm 0.005 & \pm 0.003 & \pm 0.003 & \pm 0.008 & \pm 0.3 & \pm 0.5 & \pm 0.7 & \pm 1.8 & \pm 1.4 \\
\hline \multicolumn{11}{|l|}{ B-A } \\
\hline mean paired & 0.005 & 0.010 & 0.009 & 0.010 & 0.027 & 2.2 & 3.1 & 4.9 & 6.1 & 6.6 \\
\hline difference & \pm 0.003 & \pm 0.003 & \pm 0.001 & \pm 0.002 & \pm 0.003 & \pm 0.5 & \pm 1.4 & \pm 1.2 & \pm 1.1 & \pm 1.6 \\
\hline$P$ value $\leq$ & NS & 0.05 & 0.01 & 0.01 & 0.01 & 0.01 & NS & 0.01 & 0.01 & 0.01 \\
\hline \multicolumn{11}{|l|}{ C-A } \\
\hline mean paired & 0.007 & 0.002 & 0.001 & 0.004 & -0.008 & 1.7 & 2.7 & 4.3 & 5.2 & -0.8 \\
\hline difference & \pm 0.008 & \pm 0.002 & \pm 0.003 & \pm 0.002 & \pm 0.006 & \pm 0.3 & \pm 0.6 & \pm 0.2 & \pm 0.7 & \pm 1.1 \\
\hline$P$ value $\leq$ & NS & NS & NS & NS & NS & 0.01 & 0.01 & 0.01 & 0.01 & NS \\
\hline \multicolumn{11}{|l|}{$\mathrm{D}-\mathrm{C}$} \\
\hline mean paired & 0.001 & 0.005 & 0.003 & 0.003 & 0.010 & 0.5 & 0.4 & -0.5 & -0.7 & 0.1 \\
\hline difference & \pm 0.001 & \pm 0.006 & \pm 0.003 & \pm 0.002 & \pm 0.004 & \pm 0.3 & \pm 1.1 & \pm 0.3 & \pm 0.6 & \pm 0.5 \\
\hline$P$ value $\leq$ & NS & NS & NS & NS & NS & NS & NS & NS & NS & NS \\
\hline
\end{tabular}

Values are mean $\pm S E M$ for four paired studies. Uptake values were determined at indicated times with a rapid filtration assay. Vesicles were preloaded with $1 \mathrm{mM}$ Hepes/Tris $\mathrm{pH}=7.5,180 \mathrm{mM}$ mannitol, and $40 \mathrm{mM} \mathrm{K}_{2} \mathrm{SO}_{4}$. The external incubation media contained $0.14 \mathrm{mM} \mathrm{L}-\left[{ }^{3} \mathrm{H}\right]$ glucose, $20 \mathrm{mM} \mathrm{TMA}{ }^{36} \mathrm{Cl}, 40 \mathrm{mM} \mathrm{K}_{2} \mathrm{SO}_{4}$, and either $50 \mathrm{mM} \mathrm{Hepes/Tris} \mathrm{(pH=7.5),} \mathrm{or}$ $50 \mathrm{mM} \mathrm{Mes} /$ Tris $\left(\mathrm{pH}_{\mathrm{o}}=6.0\right)$, or $50 \mathrm{mM}$ Mes/Tris $\left(\mathrm{pH}_{\mathrm{o}}=6.0\right)$ plus $30 \mathrm{mM}$ cellobiose. Final VAL concentration was 100 $\mu \mathrm{g} / \mathrm{ml}$ in series $\mathrm{D}$.

The external incubation media contained $2 \mathrm{mM}$ Tris ${ }^{36} \mathrm{Cl}, 2 \mathrm{mM} \mathrm{K} \mathrm{SO}_{4}, 35 \mathrm{mM}$ mannitol, $50 \mathrm{mM}$ Hepes/ Tris buffer, and $0.14 \mathrm{mM} \mathrm{L}-\left[{ }^{3} \mathrm{H}\right]$ glucose. The $\mathrm{pH}$ of the external media was adjusted to 7.5 (series A), 6.0 (series
B), or 4.5 (series C) with $\mathrm{H}_{2} \mathrm{SO}_{4}$. The stimulation of ${ }^{36} \mathrm{Cl}^{-}$uptake was greatest with the largest proton gradient. An overshoot was observed with both $\mathrm{pH}_{\mathrm{o}}$ $=6.0\left(\square\right.$, Fig. 5) and $\mathrm{pH}_{\mathrm{o}}=4.5(\triangle$, Fig. 5). The values

TABLE II

Effect of Hypotonic Lysis on Equilibrium Uptake Values of $\mathrm{L}-\left[{ }^{3} \mathrm{H}\right]$ Glucose and ${ }^{36} \mathrm{Cl}^{-}$

\begin{tabular}{|c|c|c|c|c|}
\hline & \multicolumn{2}{|c|}{$\mathrm{pH}_{\mathrm{o}}=7.5$} & \multicolumn{2}{|c|}{$\mathrm{pH}_{\mathrm{o}}=6.0$} \\
\hline & L- $\left[{ }^{3} \mathrm{H}\right]$ glucose & ${ }^{36} \mathrm{Cl}^{-}$ & L-[ $\left.{ }^{3} \mathrm{H}\right]$ glucose & ${ }^{36} \mathrm{Cl}^{-}$ \\
\hline & \multicolumn{4}{|c|}{ nmol/mg } \\
\hline Regular stop solution & $0.122 \pm 0.004$ & $14.6 \pm 0.7$ & $0.113 \pm 0.006$ & $13.8 \pm 0.9$ \\
\hline Distilled water stop solution & $0.011 \pm 0.001$ & $0.75 \pm 0.08$ & $0.014 \pm 0.001$ & $0.62 \pm 0.08$ \\
\hline Percent uptake & $90.3 \% \pm 1.2 \%$ & $95.0 \% \pm 0.4 \%$ & $87.2 \% \pm 0.2 \%$ & $95.8 \% \pm 0.7 \%$ \\
\hline
\end{tabular}

The vesicles were preloaded with $40 \mathrm{mM} \mathrm{K}_{2} \mathrm{SO}_{4}, 180 \mathrm{mM}$ mannitol, $1 \mathrm{mM} \mathrm{Hepes} / \mathrm{Tris}\left(\mathrm{pH}_{\mathrm{i}}=7.5\right)$. Incubation medium contained $40 \mathrm{mM} \mathrm{K}_{2} \mathrm{SO}_{4}, 20 \mathrm{mM} \mathrm{TMA}^{36} \mathrm{Cl}, 0.14 \mathrm{mM} \mathrm{L}-\left[{ }^{3} \mathrm{H}\right]$ glucose, and $50 \mathrm{mM}$ Hepes/Tris $\left(\mathrm{pH}_{\mathrm{o}}=7.5\right)$, or $50 \mathrm{mM} \mathrm{Mes} /$ Tris $\left(\mathrm{pH}_{\mathrm{o}}=6.0\right)$ plus $30 \mathrm{mM}$ cellobiose. Equilibrium uptakes were assayed in triplicate at $120 \mathrm{~min}$. The results are presented as mean $\pm \mathrm{SEM}$ for three separate experiments. Percent uptake was calculated as $100 \times($ regular stop - distilled water $) /$ regular stop. 


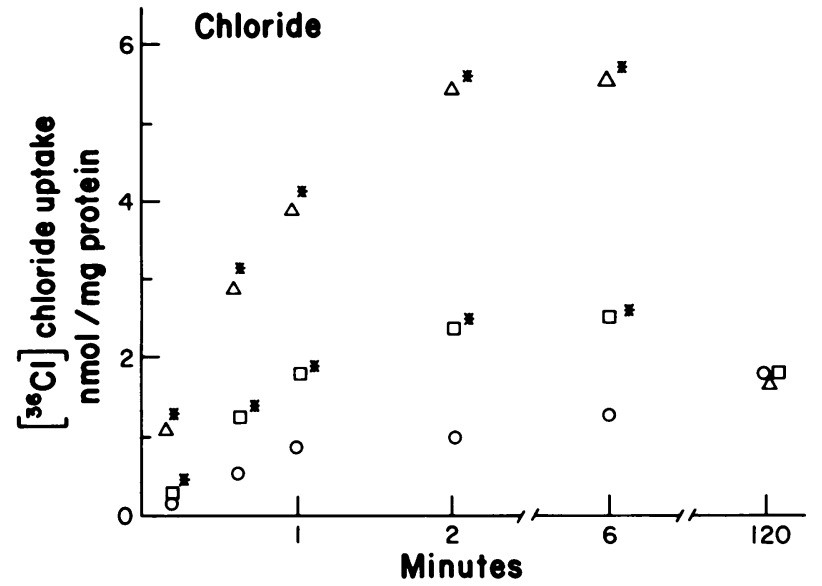

FIGURE 5 Uptake of ${ }^{36} \mathrm{Cl}^{-}$by brush border membrane vesicles: effect of inwardly directed proton gradients. Vesicles were preloaded with $2 \mathrm{mM} \mathrm{K}_{2} \mathrm{SO}_{4}, 100 \mathrm{mM}$ mannitol, and $10 \mathrm{mM}$ Hepes/Tris buffer $\left(\mathrm{pH}_{\mathrm{i}}=7.5\right)$. The external incubation media contained $2 \mathrm{mM}$ Tris ${ }^{36} \mathrm{Cl}, 2 \mathrm{mM} \mathrm{K}_{2} \mathrm{SO}_{4}, 35 \mathrm{mM}$ mannitol, $50 \mathrm{mM}$ Hepes/Tris buffer, and $0.14 \mathrm{mM} \mathrm{L}^{-}\left[{ }^{3} \mathrm{H}\right]$ glucose. The $\mathrm{pH}$ of the external incubation media was adjusted with $\mathrm{H}_{2} \mathrm{SO}_{4}$ to the indicated values before initiating the uptake studies. The external $\mathrm{pH}$ was $7.5(O), 6.0(\square)$, or $4.5(\triangle)$. Starred values $\left({ }^{*}\right)$ are significantly different from the control series $(P \leq 0.05 ; n=5$ paired studies).

for ${ }^{36} \mathrm{Cl}^{-}$uptake at 2 and 6 min significantly exceeded the final equilibrium values at $120 \mathrm{~min}$ when $\mathrm{pH}_{\mathrm{o}}$ $=6.0$ ( $\square$, Fig. 5). The overshoot was even more prominent with $\mathrm{pH}_{\mathrm{o}}=4.5$, and was observed as early as $0.5 \mathrm{~min}$. The $120 \mathrm{~min}$ equilibrium values were independent of external $\mathrm{pH}$.

These results are summarized in Table III. The L$\left[{ }^{3} \mathrm{H}\right]$ glucose values were identical for 0.15 to $6.0 \mathrm{~min}$ (compare series $\mathrm{B}$ and $\mathrm{C}$ to $\mathrm{A}$, Table III). The final equilibrium values for $\mathrm{L}-\left[{ }^{3} \mathrm{H}\right]$ glucose uptake were significantly different. The final intravesicular volume decreased in more acidic media. However, the overshoot in ${ }^{36} \mathrm{Cl}^{-}$uptake was observed at the initial time points when the L- $\left[{ }^{3} \mathrm{H}\right]$ glucose uptake values were identical for series A, B, and C (Table III).

The uptakes of $\mathrm{L}-\left[{ }^{3} \mathrm{H}\right]$ glucose and ${ }^{36} \mathrm{Cl}^{-}$when both internal and external $\mathrm{pH}$ were 6.0 were measured in series $\mathrm{D}$, Table III. The $\mathrm{L}-\left[{ }^{3} \mathrm{H}\right]$ glucose uptake values at each time point, including $120 \mathrm{~min}$, were identical to those obtained when $\mathrm{pH}_{\mathrm{o}}=\mathrm{pH}_{\mathrm{i}}=7.5$. (compare series $A$ and $D$, Table III). Although there was a slight stimulation of ${ }^{36} \mathrm{Cl}^{-}$uptake at $2 \mathrm{~min}$, the marked stimulation of ${ }^{36} \mathrm{Cl}^{-}$uptake by inwardly directed proton gradients was not observed (compare series B and D, Table III). Similar results were obtained when $\mathrm{pH}_{\mathrm{o}}$ $=\mathrm{pH}_{\mathrm{i}}=4.5$ (series $\mathrm{E}$, Table III). There were slight increases in $\mathrm{L}-\left[{ }^{3} \mathrm{H}\right]$ glucose uptake at 2 and $6 \mathrm{~min}$, and a fall in the ${ }^{36} \mathrm{Cl}^{-}$equilibrium value (compare series $\mathrm{E}$ and $\mathrm{A}$, Table III). Again, marked stimulation of
${ }^{36} \mathrm{Cl}^{-}$uptake was not observed when the vesicles were preequilibrated at $\mathrm{pH}_{0}=4.5$ (compare series $\mathrm{C}$ and $\mathrm{E}$, Table III). We interpret these results as demonstrating coupling of ${ }^{36} \mathrm{Cl}^{-}$uptake to inwardly directed proton gradients in brush border membrane vesicles from the rabbit renal cortex. This effect does not appear to be explained by some nonspecific effect on membrane permeability because it is observed when intravesicular volume was increased (series B, Table I), decreased (series B and C, Table III) or remained the same (series C, Table I). The results presented in Table III demonstrate that ${ }^{36} \mathrm{Cl}^{-}$uptake is coupled to inwardly directed proton gradients, and is only slightly stimulated by external acidity per se.

Effects of both proton gradients and $\mathrm{K}^{+}$diffusion potentials on ${ }^{36} \mathrm{Cl}^{-}$uptake. The next series examined the separate effects of proton gradients and $\mathrm{K}^{+}$diffusion PD (plus VAL) on ${ }^{36} \mathrm{Cl}^{-}$uptake (Table IV). Vesicles were preloaded with $40 \mathrm{mM} \mathrm{MgSO}, 120 \mathrm{mM}$ mannitol, and $50 \mathrm{mM}$ Hepes/Tris buffer $\left(\mathrm{pH}_{\mathrm{i}}=7.5\right)$. The external incubation media contained $40 \mathrm{mM} \mathrm{K}_{2} \mathrm{SO}_{4}$, $20 \mathrm{mM} \mathrm{TMA}^{36} \mathrm{Cl}, 40 \mathrm{mM}$ mannitol, and either $50 \mathrm{mM}$ Hepes/Tris (pH 7.5) buffer or $50 \mathrm{mM}$ Mes/Tris (pH 6.0) buffer. Uptake values at $1 \mathrm{~min}$ are presented in Table IV. The increase in uptake when $\mathrm{pH}_{\mathrm{o}}=6.0$ is shown in the first column (mean paired difference $=3.9 \pm 0.8 \mathrm{nmol} / \mathrm{mg}, n=8, P \leq 0.01)$. An inwardly directed $\mathrm{K}^{+}$diffusion PD (plus VAL) increased ${ }^{36} \mathrm{Cl}^{-}$ uptake at either external $\mathrm{pH}\left(\right.$ for $\mathrm{pH}_{\mathrm{o}}=7.5$, mean paired differerence $=2.2 \pm 0.6 \mathrm{nmol} / \mathrm{mg}, n=8, P \leq 0.01$; for $\mathrm{pH}_{\mathrm{o}}=6.0$, mean paired difference $=2.7 \pm 0.7 \mathrm{nmol} / \mathrm{mg}$, $n=8, P \leq 0.05)$. The increases in ${ }^{36} \mathrm{Cl}^{-}$uptake with VAL at either external pH were not significantly different. Similarly, the increases in ${ }^{36} \mathrm{Cl}^{-}$uptake with inwardly directed proton gradients with and without VAL were not significantly different. These results demonstrate that ${ }^{36} \mathrm{Cl}^{-}$uptake coupled to inwardly directed proton gradients and ${ }^{36} \mathrm{Cl}^{-}$uptake driven by electrical forces utilize transport pathways that are additive. These results could be explained by summation of two distinct transport pathways, or by a single pathway if the uptake of ${ }^{36} \mathrm{Cl}^{-}$is limited by the rate of uptake of the accompanying cation.

The possibility that separate transport pathways couple ${ }^{36} \mathrm{Cl}^{-}$uptake to electrical driving forces and to proton gradients was examined by investigating the competitive effects of various anions under either condition. Series A was done with an inwardly directed proton gradient, and the results are presented in Table V. Vesicles were preloaded with $80 \mathrm{mM}$ potassium gluconate, $140 \mathrm{mM}$ mannitol, and $1 \mathrm{mM}$ Hepes/ Tris buffer $\left(\mathrm{pH}_{\mathrm{i}}=7.5\right)$. The external incubation media contained $20 \mathrm{mM} \mathrm{K}{ }^{36} \mathrm{Cl}, 50 \mathrm{mM} \mathrm{Mes} /$ Tris buffer $\left(\mathrm{pH}_{\mathrm{o}}=6.0\right), 0.14 \mathrm{mM} \mathrm{L}-\left[{ }^{3} \mathrm{H}\right] \mathrm{glucose}$ and $80 \mathrm{mM}$ of $\mathrm{K}^{+}$with each of the various anions which are listed in Table V (40 mM mannitol was also added when the 
TABLE III

Effects of $p H$ Gradients on $\mathrm{L}-\left[{ }^{3} \mathrm{H}\right]$ Glucose and ${ }^{36} \mathrm{Cl}^{-}$Uptake by Renal Brush Border Vesicles

\begin{tabular}{|c|c|c|c|c|c|c|c|c|c|c|c|c|}
\hline & \multicolumn{6}{|c|}{ L-[ $\left.{ }^{3} \mathrm{H}\right]$ Glucose uptake (nmol/mg) } & \multicolumn{6}{|c|}{${ }^{36} \mathrm{Cl}^{-}$uptake $(\mathrm{nmol} / \mathrm{mg})$} \\
\hline & $\begin{array}{l}0.15 \\
\min \end{array}$ & $\begin{array}{c}0.5 \\
\min \end{array}$ & $\begin{array}{l}1.0 \\
\min \end{array}$ & $\begin{array}{l}2.0 \\
\mathrm{~min}\end{array}$ & $\begin{array}{l}6.0 \\
\min \end{array}$ & $\begin{array}{l}120 \\
\mathrm{~min}\end{array}$ & $\begin{array}{l}0.15 \\
\min \end{array}$ & $\begin{array}{l}0.5 \\
\min \end{array}$ & $\begin{array}{l}1.0 \\
\mathrm{~min}\end{array}$ & $\begin{array}{c}2.0 \\
\min \end{array}$ & $\begin{array}{c}6.0 \\
\mathrm{~min}\end{array}$ & $\begin{array}{l}120 \\
\min \end{array}$ \\
\hline \multicolumn{13}{|c|}{$\begin{array}{l}\text { Internal } \mathrm{pH}=7.5 \\
\text { External pH: }\end{array}$} \\
\hline A 7.5 & $\begin{array}{r}0.004 \\
\pm 0.006\end{array}$ & $\begin{array}{r}0.016 \\
\pm 0.007\end{array}$ & $\begin{array}{r}0.026 \\
\pm 0.007\end{array}$ & $\begin{array}{r}0.034 \\
\pm 0.007\end{array}$ & $\begin{array}{r}0.053 \\
\pm 0.011\end{array}$ & $\begin{array}{r}0.164 \\
\pm 0.016\end{array}$ & $\begin{array}{r}0.12 \\
\pm 0.08\end{array}$ & $\begin{array}{r}0.55 \\
\pm 0.14\end{array}$ & $\begin{array}{r}0.79 \\
\pm 0.15\end{array}$ & $\begin{array}{r}0.83 \\
\pm 0.15\end{array}$ & $\begin{array}{r}1.19 \\
\pm 0.15\end{array}$ & $\begin{array}{r}1.64 \\
\pm 0.19\end{array}$ \\
\hline B 6.0 & $\begin{array}{r}0.003 \\
\pm 0.005\end{array}$ & $\begin{array}{r}0.017 \\
\pm 0.006\end{array}$ & $\begin{array}{r}0.024 \\
\pm 0.007\end{array}$ & $\begin{array}{r}0.034 \\
\pm 0.007\end{array}$ & $\begin{array}{r}0.055 \\
\pm 0.010\end{array}$ & $\begin{array}{r}0.141 \\
\pm 0.016\end{array}$ & $\begin{array}{r}0.33 \\
\pm 0.08\end{array}$ & $\begin{array}{r}1.27 \\
\pm 0.12\end{array}$ & $\begin{array}{r}1.77 \\
\pm 0.17\end{array}$ & $\begin{array}{r}2.3 .3 \\
\pm 0.25\end{array}$ & $\begin{array}{r}2.47 \\
\pm 0.21\end{array}$ & $\begin{array}{r}1.66 \\
\pm 0.12\end{array}$ \\
\hline C 4.5 & $\begin{array}{r}0.006 \\
\pm 0.007\end{array}$ & $\begin{array}{r}0.021 \\
\pm 0.008\end{array}$ & $\begin{array}{r}0.028 \\
\pm 0.007\end{array}$ & $\begin{array}{r}0.038 \\
\pm 0.007\end{array}$ & $\begin{array}{r}0.058 \\
\pm 0.009\end{array}$ & $\begin{array}{r}0.130 \\
\pm 0.015\end{array}$ & $\begin{array}{r}1.14 \\
\pm 0.27\end{array}$ & $\begin{array}{r}2.84 \\
\pm 0.42\end{array}$ & $\begin{array}{r}3.96 \\
\pm 0.41\end{array}$ & $\begin{array}{r}5.11 \\
\pm 0.47\end{array}$ & $\begin{array}{r}5.47 \\
\pm 0.47\end{array}$ & $\begin{array}{r}1.55 \\
\pm 0.15\end{array}$ \\
\hline \multicolumn{13}{|l|}{$\begin{array}{l}\text { External and } \\
\text { internal pH: }\end{array}$} \\
\hline D 6.0 & $\begin{array}{r}0.001 \\
\pm 0.007\end{array}$ & $\begin{array}{r}0.016 \\
\pm 0.006\end{array}$ & $\begin{array}{r}0.022 \\
\pm 0.006\end{array}$ & $\begin{array}{r}0.037 \\
\pm 0.008\end{array}$ & $\begin{array}{r}0.057 \\
\pm 0.008\end{array}$ & $\begin{array}{r}0.154 \\
\pm 0.015\end{array}$ & $\begin{array}{r}0.12 \\
\pm 0.06\end{array}$ & $\begin{array}{r}0.74 \\
\pm 0.11\end{array}$ & $\begin{array}{r}1.04 \\
\pm 0.11\end{array}$ & $\begin{array}{r}1.27 \\
\pm 0.17\end{array}$ & $\begin{array}{r}1.60 \\
\pm 0.17\end{array}$ & $\begin{array}{r}1.68 \\
\pm 0.20\end{array}$ \\
\hline E 4.5 & $\begin{array}{r}0.008 \\
\pm 0.005\end{array}$ & $\begin{array}{r}0.027 \\
\pm 0.007\end{array}$ & $\begin{array}{r}0.035 \\
\pm 0.003\end{array}$ & $\begin{array}{r}0.044 \\
\pm 0.003\end{array}$ & $\begin{array}{r}0.073 \\
\pm 0.006\end{array}$ & $\begin{array}{r}0.135 \\
\pm 0.009\end{array}$ & $\begin{array}{r}0.11 \\
\pm 0.17\end{array}$ & $\begin{array}{r}0.59 \\
\pm 0.29\end{array}$ & $\begin{array}{r}0.76 \\
\pm 0.36\end{array}$ & $\begin{array}{r}0.79 \\
\pm 0.36\end{array}$ & $\begin{array}{r}0.71 \\
\pm 0.44\end{array}$ & $\begin{array}{r}0.08 \\
\pm 0.13\end{array}$ \\
\hline \multicolumn{13}{|l|}{ B-A } \\
\hline $\begin{array}{l}\text { mean paired } \\
\text { difference } \\
P \text { value }\end{array}$ & $\begin{array}{c}-0.001 \\
\pm 0.003 \\
\text { NS }\end{array}$ & $\begin{array}{c}0.001 \\
\pm 0.004 \\
\text { NS }\end{array}$ & $\begin{array}{c}-0.001 \\
\pm 0.004 \\
\text { NS }\end{array}$ & $\begin{array}{c}0.004 \\
\pm 0.003 \\
\text { NS }\end{array}$ & $\begin{array}{c}0.002 \\
\pm 0.001 \\
N S\end{array}$ & $\begin{array}{c}-0.023 \\
\pm 0.008 \\
0.05\end{array}$ & $\begin{array}{c}0.21 \\
\pm 0.08 \\
\text { NS }\end{array}$ & $\begin{array}{r}0.71 \\
\pm 0.15 \\
0.01\end{array}$ & $\begin{array}{r}0.96 \\
\pm 0.23 \\
0.05\end{array}$ & $\begin{array}{r}1.50 \\
\pm 0.26 \\
0.01\end{array}$ & $\begin{array}{r}1.29 \\
\pm 0.21 \\
0.01\end{array}$ & $\begin{array}{c}0.02 \\
\pm 0.13 \\
\text { NS }\end{array}$ \\
\hline \multicolumn{13}{|l|}{ C-A } \\
\hline $\begin{array}{l}\text { mean paired } \\
\text { difference } \\
P \text { value }\end{array}$ & $\begin{array}{c}0.002 \\
\pm 0.003 \\
\text { NS }\end{array}$ & $\begin{array}{c}0.005 \\
\pm 0.003 \\
\text { NS }\end{array}$ & $\begin{array}{c}0.002 \\
\pm 0.003 \\
\text { NS }\end{array}$ & $\begin{array}{c}0.004 \\
\pm 0.002 \\
\text { NS }\end{array}$ & $\begin{array}{c}0.005 \\
\pm 0 .(003 \\
\text { NS }\end{array}$ & $\begin{array}{c}-0.035 \\
\pm 0.005 \\
0.01\end{array}$ & $\begin{array}{r}1.01 \\
\pm 0.21 \\
0.01\end{array}$ & $\begin{array}{r}2.28 \\
\pm 0.37 \\
0.01\end{array}$ & $\begin{array}{r}3.17 \\
\pm 0.42 \\
0.01\end{array}$ & $\begin{array}{r}4.48 \\
\pm 0.41 \\
0.01\end{array}$ & $\begin{array}{r}4.29 \\
\pm 0.46 \\
0.01\end{array}$ & $\begin{array}{c}-0.09 \\
\pm 0.08 \\
\text { NS }\end{array}$ \\
\hline \multicolumn{13}{|l|}{ D-A } \\
\hline $\begin{array}{l}\text { mean paired } \\
\text { difference } \\
P \text { value }\end{array}$ & $\begin{array}{c}-0.003 \\
\pm 0.005 \\
\text { NS }\end{array}$ & $\begin{array}{c}-0.001 \\
\pm 0.005 \\
\text { NS }\end{array}$ & $\begin{array}{c}-0.004 \\
\pm 0.005 \\
\text { NS }\end{array}$ & $\begin{array}{c}0.007 \\
\pm 0.005 \\
\text { NS }\end{array}$ & $\begin{array}{c}0.004 \\
\pm 0.006 \\
\mathrm{NS}\end{array}$ & $\begin{array}{c}-0.011 \\
\pm 0.013 \\
\mathrm{NS}\end{array}$ & $\begin{array}{c}0.01 \\
\pm 0.04 \\
\text { NS }\end{array}$ & $\begin{array}{c}0.19 \\
\pm 0.14 \\
\text { NS }\end{array}$ & $\begin{array}{c}0.24 \\
\pm 0.11 \\
\mathrm{NS}\end{array}$ & $\begin{array}{r}0.44 \\
\pm 0.14 \\
0.05\end{array}$ & $\begin{array}{c}0.21 \\
\pm 0.08 \\
\text { NS }\end{array}$ & $\begin{array}{c}0.26 \\
\pm 0.10 \\
\mathrm{NS}\end{array}$ \\
\hline \multicolumn{13}{|l|}{ E-A } \\
\hline $\begin{array}{l}\text { mean paired } \\
\text { difference } \\
P \text { value }\end{array}$ & $\begin{array}{r}0.006 \\
\pm 0.007 \\
\text { NS }\end{array}$ & $\begin{array}{l}0.015 \\
\pm 0.010 \\
\text { NS }\end{array}$ & $\begin{array}{r}0.015 \\
\pm 0.006 \\
\text { NS }\end{array}$ & $\begin{array}{c}0.020 \\
\pm 0.004 \\
0.01\end{array}$ & $\begin{array}{r}0.028 \\
\pm 0.006 \\
0.01\end{array}$ & $\begin{array}{l}-0.017 \\
\pm 0.018 \\
\text { NS }\end{array}$ & $\begin{array}{c}0.09 \\
\pm 0.22 \\
\text { NS }\end{array}$ & $\begin{array}{r}0.12 \\
\pm 0.33 \\
\text { NS }\end{array}$ & $\begin{array}{r}0.08 \\
\pm 0.42 \\
\text { NS }\end{array}$ & $\begin{array}{r}0.04 \\
\pm 0.39 \\
\text { NS }\end{array}$ & $\begin{array}{l}-0.33 \\
\pm 0.48 \\
\text { NS }\end{array}$ & $\begin{array}{r}-1.41 \\
\pm 0.21 \\
0.01\end{array}$ \\
\hline
\end{tabular}

Values are mean $\pm S E M$ for five paired studies. Uptake values were determined at indicated times with a rapid filtration assay. Vesicles were preloaded with $100 \mathrm{mM}$ mannitol, $2 \mathrm{mM} \mathrm{K}_{2} \mathrm{SO}_{4}$, and $10 \mathrm{mM}$ Hepes/Tris buffer. The internal $\mathrm{pH}$ was 7.5 for series A-C, 6.0 for series D, and 4.5 for series $\mathrm{E}$; $\mathrm{pH}$ was adjusted with $\mathrm{H}_{2} \mathrm{SO}_{4}$ and the vesicles preequilibrated for $1 \mathrm{~h}$. The external incubation media contained $2 \mathrm{mM}$ Tris ${ }^{36} \mathrm{Cl}, 2 \mathrm{mK} \mathrm{K} \mathrm{SO}_{4}, 35 \mathrm{mM}$ mannitol, $50 \mathrm{mM}$ Hepes/Tris buffer, and $0.14 \mathrm{mM} \mathrm{L}-\left[{ }^{3} \mathrm{H}\right]$ glucose. The $\mathrm{pH}$ of the external incubation media was adjusted to the indicated values with $\mathrm{H}_{2} \mathrm{SO}_{4}$ before initiating the uptake studies.

external incubation contained $40 \mathrm{mM} \mathrm{K}_{2} \mathrm{SO}_{4}$ ). The uptake of ${ }^{36} \mathrm{Cl}^{-}$in the presence of $80 \mathrm{mM}$ unlabeled $\mathrm{KCl}$ was assigned an arbitrary value of $100 \%$, and the uptake values in the presence of the other anions was expressed as a percentage of the rate observed with $80 \mathrm{mM}$ unlabeled $\mathrm{KCl}$. Uptake values were normalized by the $\mathrm{L}-\left[{ }^{3} \mathrm{H}\right]$ glucose uptake values as indicated in the legend of Table V. The uptake values were normalized by the simultaneously determined L- $\left[{ }^{3} \mathrm{H}\right]$ glucose uptake values to control for any osmotic effects that the various salts may have exerted on the intravesicular volume. Gluconate and $\mathrm{SO}_{4}^{=}$did not inhibit ${ }^{36} \mathrm{Cl}^{-}$uptake at $\mathrm{pH}_{0}=6.0$ as effectively as unlabeled chloride. Acetate and $\mathrm{SCN}^{-}$(potassium thiocyanate) had intermediate effects, and $\mathrm{NO}_{3}^{-}, \mathrm{Br}^{-}$, and
$I^{-}$were about as effective as unlabeled chloride in the proton-driven mode.

Similar studies were done to describe the conductive mode of ${ }^{36} \mathrm{Cl}^{-}$uptake (series B, Table V). Vesicles were preloaded with $300 \mathrm{mM}$ mannitol, $1 \mathrm{mM}$ Hepes/ Tris buffer $\left(\mathrm{pH}_{\mathrm{i}}=7.5\right)$, and $100 \mu \mathrm{g} / \mathrm{ml}$ VAL. The external incubation media were similar to those used in series A except that the external buffer was $50 \mathrm{mM}$ Hepes/Tris ( $\mathrm{pH}$ 7.5). These results are also expressed relative to the uptake of ${ }^{36} \mathrm{Cl}^{-}$in the presence of 80 $\mathrm{mM}$ unlabeled $\mathrm{KCl}$. Note that the external $\left[\mathrm{K}^{+}\right]$was always $100 \mathrm{mM}$ so the magnitude of the inwardly directed $\mathrm{K}^{+}$diffusion PD (plus VAL) was presumably the same in each case. Gluconate and $\mathrm{SO}_{4}^{=}$did not inhibit ${ }^{36} \mathrm{Cl}^{-}$uptake as well as unlabeled chloride, 
TABLE IV

Effects of $p H$ Gradients and $\mathrm{K}^{+}$Gradients Plus VAL on ${ }^{36} \mathrm{Cl}^{-}$Uptake by Renal Brush Border Vesicles

\begin{tabular}{ccccc}
\hline External pH & $\begin{array}{c}{ }^{\star} \mathrm{Cl}^{-} \text {uptake } \\
(\mathrm{nmol} / \mathrm{mg} \text { at } 1 \text { min) }\end{array}$ & $\begin{array}{c}\text { Mean paired } \\
\text { difference }\end{array}$ & P value $\leq$ \\
\hline & $-\mathrm{VAL}$ & $+\mathrm{VAL}$ & & \\
7.5 & $5.1 \pm 0.7$ & $7.3 \pm 1.1$ & $2.2 \pm 0.6$ & 0.01 \\
6.0 & $8.9 \pm 1.5$ & $11.7 \pm 1.6$ & $2.7 \pm 0.7$ & 0.01 \\
Mean paired & & & & \\
difference & $3.9 \pm 0.8$ & $4.3 \pm 1.0$ & & \\
$P$ value $\leq$ & 0.01 & 0.01 & & \\
\hline
\end{tabular}

Values are mean \pm SEM for eight paired studies. Uptake values were determined at $1 \mathrm{~min}$ with a rapid filtration assay. Vesicles were preloaded with $40 \mathrm{mM} \mathrm{MgSO}, 120 \mathrm{mM}$ mannitol, and $50 \mathrm{mM}$ Hepes/Tris $\left(\mathrm{pH}_{\mathrm{i}}=7.5\right)$. External incubation media contained $40 \mathrm{mM} \mathrm{K}_{2} \mathrm{SO}_{4}, 20 \mathrm{mM} \mathrm{TMA}{ }^{36} \mathrm{Cl}$, $40 \mathrm{mM}$ mannitol, and either $50 \mathrm{mM}$ Hepes/Tris $\left(\mathrm{pH}_{\mathrm{o}}=7.5\right)$ or $50 \mathrm{mM} \mathrm{Mes} /$ Tris $\left(\mathrm{pH}_{\mathrm{o}}=6.0\right)$. When present, final VAL concentration was $100 \mu \mathrm{g} / \mathrm{ml}$.

similar to their effects in series A. Acetate had an intermediate effect, and $\mathrm{SCN}^{-}, \mathrm{NO}_{3}^{-}, \mathrm{Br}^{-}$and $\mathrm{I}^{-}$were more effective (i.e., uptake $<100 \%$ ) than unlabeled chloride. The rank-order of competitive effects is qualitatively different in the conductive mode (series B, Table V):

$\mathrm{SCN}^{-}>\mathrm{I}^{-}>\mathrm{NO}_{3}^{-}=\mathrm{Br}^{-}>\mathrm{Cl}^{-}>$acetate

$$
>\mathrm{SO}_{4}^{\overline{=}}>\text { gluconate, }
$$

compared with the proton-driven mode (series A, Table V):

$$
\begin{aligned}
\mathrm{Cl}^{-}=\mathrm{I}^{-}>\mathrm{Br}^{-}>\mathrm{NO}_{3}^{-}>\mathrm{SCN}^{-}>\text {acetate } & \\
& >\mathrm{SO}_{4}^{-}>\text {gluconate. }
\end{aligned}
$$

\section{DISCUSSION}

Chloride transport mechanisms. These studies demonstrate a conductive (i.e., electro-diffusional) pathway for chloride transport in brush border membrane vesicles prepared from rabbit kidney cortex. This mode of chloride uptake is coupled to inwardly directed $\mathrm{K}^{+}$gradients plus VAL, presumably by the $\mathrm{K}^{+}$ diffusion PD (interior-positive) developed with VAL $(46,47)$. The conductive mode can be demonstrated in the presence or absence of $\mathrm{Na}^{+}$in the incubation media (Figs. 1 and 2). The inhibition of the $\mathrm{Na}^{+}$coupled overshoot of $\mathrm{D}-\left[{ }^{3} \mathrm{H}\right]$ glucose uptake with concomitant stimulation of ${ }^{36} \mathrm{Cl}^{-}$uptake by an inwardly directed $\mathrm{K}^{+}$gradient plus VAL is consistent with the electrogenic nature of the sodium-coupled glucose cotransport mechanism (7-18). The presence of an anionic conductance pathway has been inferred from the effects of anions on $\mathrm{Na}^{+}$-coupled $\mathrm{D}-\left[{ }^{3} \mathrm{H}\right]$ glucose transport rates and on the overshoot (7-17); permeable anions like thiocyanate, nitrate, and chloride produce larger overshoots than less permeable anions like sulfate or cyclamate. The present studies provide evidence for the presence of a chloride-conductive pathway, confirming previous inferences about the nature of anion transport in brush border vesicles prepared from renal cortex or intestine (7-18, 31-33). Furthermore, the apparent anion selectivity of the conductive mode (series $\mathrm{B}$, Table $\mathrm{V}$ ) is identical to that predicted from the overshoot phenomena (7-18): $\mathrm{SCN}^{-}>\mathrm{NO}_{3}^{-}>\mathrm{Cl}^{-} \gg \mathrm{SO}_{4}^{-}$.

The effects of various anions on ${ }^{36} \mathrm{Cl}^{-}$uptake (Table V) represent inhibition relative to that observed with unlabeled chloride. Further studies are required to determine the mechanisms by which a specific anion inhibits ${ }^{36} \mathrm{Cl}^{-}$uptake. Reduced ${ }^{36} \mathrm{Cl}^{-}$uptake may represent competitive inhibition at a particular anionic

TABLE V

Effects of Various Anions on ${ }^{36} \mathrm{Cl}^{-}$Uptake by Renal Brush Border Vesicles

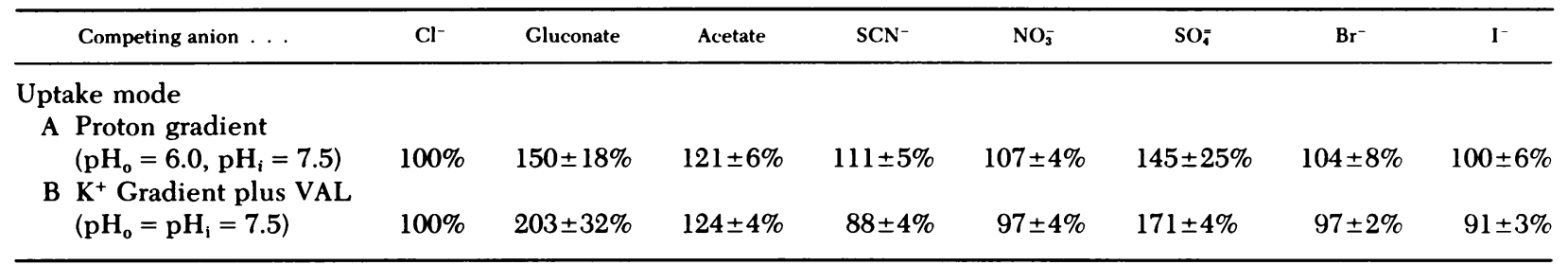

Values are mean \pm SEM for at least five studies. ${ }^{36} \mathrm{Cl}^{-}$uptake was measured at 1 min with a rapid filtration assay. In series $\mathrm{A}$, vesicles were preloaded with $80 \mathrm{mM}$ KGluconate, $140 \mathrm{mM}$ mannitol, and $1 \mathrm{mM}$ Hepes/Tris $\left(\mathrm{pH}_{\mathrm{i}}=7.5\right)$ buffer. The external incubation media contained $20 \mathrm{mM} \mathrm{K}{ }^{36} \mathrm{Cl}, 50 \mathrm{mM} \mathrm{Mes} /$ Tris $\left(\mathrm{pH} 6.0\right.$ ) buffer, $0.14 \mathrm{mM} \mathrm{L}-\left[{ }^{3} \mathrm{H}\right]$ glucose, $80 \mathrm{mM} \mathrm{K}{ }^{+}$, and the various anions indicated in the table. In series $B$, vesicles were preloaded with $300 \mathrm{mM}$ mannitol, $1 \mathrm{mM} \mathrm{Hepes/Tris}\left(\mathrm{pH} \mathrm{m}_{\mathrm{i}}=7.5\right.$ ) buffer, and VAL $\left(100 \mu \mathrm{g} / \mathrm{ml}\right.$ ). The external incubation media contained $20 \mathrm{mM} \mathrm{K}{ }^{36} \mathrm{Cl}, 50 \mathrm{mM}$ Hepes/Tris (pH 7.5) buffer, $0.14 \mathrm{mM} \mathrm{L}-\left[{ }^{3} \mathrm{H}\right]$ glucose, $80 \mathrm{mM} \mathrm{K} \mathrm{K}^{+}$, and the various anions indicated in the table. $40 \mathrm{mM}$ mannitol was also added when the external incubation media contained $40 \mathrm{mM} \mathrm{K} \mathrm{SO}_{4}$. Results are expressed relative to ${ }^{36} \mathrm{Cl}^{-}$uptake (normalized for $\mathrm{L}-\left[{ }^{3} \mathrm{H}\right]$ glucose uptake) measured in the presence of $80 \mathrm{mM}$ unlabeled $\mathrm{KCl}$ : \% uptake $=100 \times\left({ }^{36} \mathrm{Cl}^{-}\right.$uptake/L- $\left.{ }^{3} \mathrm{H}\right] \mathrm{glucose}$ uptake $)_{\mathrm{K} \text { anion }} /\left({ }^{36} \mathrm{Cl}^{-} \text {uptake/L- }\left[{ }^{3} \mathrm{H}\right] \text { glucose uptake }\right)_{\mathrm{KCl}}$. 
binding or transport site, noncompetitive inhibition due to interaction at some other membrane site, or diffusion of the anion through the lipid portion of the membrane, resulting in collapse of the driving force for ${ }^{36} \mathrm{Cl}^{-}$uptake.

Coupling of ${ }^{36} \mathrm{Cl}^{-}$uptake to inwardly directed proton gradients was demonstrated by the results in Tables I and III. Stimulation of uptake above the equilibrium value (overshoot) was more prominent with larger proton gradients (series D and E, Table III). This effect does not seem to be due to some nonspecific effect on membrane permeability because $(a)$ membrane-binding of ${ }^{36} \mathrm{Cl}^{-}$and $\mathrm{L}_{-}\left[{ }^{3} \mathrm{H}\right]$ glucose was unaffected by external pH (Table II), and ( $b$ ) the stimulation of ${ }^{36} \mathrm{Cl}^{-}$uptake could be dissociated from changes in intravesicular volume (compare series $B$ and $C$, Table I and A, B, and C in Table III).

Our present studies do not permit any definitive statement concerning the mechanism by which ${ }^{36} \mathrm{Cl}^{-}$ uptake is coupled to proton gradients. Two possibilities could explain these results: electrically neutral transport (i.e., $\mathrm{HCl}$ symport, $\mathrm{Cl}^{-} / \mathrm{OH}^{-}$antiport), or conductive transport driven by an interior positive $\mathrm{H}^{+}$ diffusion $P D$ due to the inwardly directed proton gradient. The latter explanation requires a parallel conductance pathway for protons through the membrane. Previous workers have concluded that the $\mathrm{Na}^{+} / \mathrm{H}^{+}$antiport is electrically neutral, and that the protonic conductance of the brush border membrane vesicle is very low $(30,58)$. If this previous conclusion is correct, then our results cannot be explained by electrical coupling between protons and chloride. However, the anionic conductance pathway complicates any further interpretation. For example, if a protonic ionophore is added to an imposed proton gradient, then transport of ${ }^{36} \mathrm{Cl}^{-}$via its conductance pathway will occur, regardless of the intrinsic mechanism of coupling of ${ }^{36} \mathrm{Cl}^{-}$uptake to the proton gradient. This is not an issue in studies of the $\mathrm{Na}^{+} / \mathrm{H}^{+}$ antiport because the sodium conductance of the brush border vesicle appears to be very low in the absence of cotransported organic solutes $(30,58)$.

$\mathrm{VAL}$, a $\mathrm{K}^{+}$ionophore, was used to investigate the possibility that electrical effects may explain the coupling between proton gradients and ${ }^{36} \mathrm{Cl}^{-}$uptake. Vesicles were preequilibrated with VAL and $80 \mathrm{mM}$ $\mathrm{K}^{+}$in series $\mathrm{D}$, Table I. A concentration of VAL (100 $\mu \mathrm{g} / \mathrm{ml}$ ) was used that was shown to create a conductance pathway for $\mathrm{K}^{+}$transport (Figs. 1 and 2). No effect of VAL on proton-driven ${ }^{36} \mathrm{Cl}^{-}$uptake was observed when $\left[\mathrm{K}^{+}\right]_{\mathrm{o}}=\left[\mathrm{K}^{+}\right]_{\mathrm{i}}=80 \mathrm{mM}$ (compare series $\mathrm{D}$ to $\mathrm{C}$, Table I). If $\mathrm{K}^{+}$conductance exceeded $\mathrm{H}^{+}$conductance in this setting, then any diffusion PD due to the proton gradient would have been shunted by parallel movement of compensating charge (i.e., $\mathrm{K}^{+}$agress). This possibility seems plausible when the low protonic conductance $(30,58)$ and the relative magnitudes of $\mathrm{K}^{+}$and $\mathrm{H}^{+}$concentrations (80 and $0.001 \mathrm{mM}$, respectively) are considered. Another line of evidence may be developed with the $\mathrm{SCN}^{-}$inhibition data in Table V. SCN ${ }^{-}$is a lipophilic anion, and is the most effective anionic inhibitor of ${ }^{36} \mathrm{Cl}^{-}$uptake in the conductive mode (series $\mathrm{B}$, Table $\mathrm{V}$ ). If the proton-driven mode is an electro-diffusional mechanism, then one could predict that $\mathrm{SCN}^{-}$would also compete for ${ }^{36} \mathrm{Cl}^{-}$ uptake in series $\mathrm{A}$, Table $\mathrm{V}$. In fact, $\mathrm{SCN}^{-}$does not significantly inhibit ${ }^{36} \mathrm{Cl}^{-}$uptake in the proton-driven mode, whereas in the conductive mode, $\mathrm{SCN}^{-}$significantly inhibits ${ }^{36} \mathrm{Cl}^{-}$uptake (mean paired difference $12.2 \pm 4.0 \%, n=5, P<0.05)$. These results imply that the proton-driven mode of ${ }^{36} \mathrm{Cl}^{-}$uptake does not represent a conductive transport mechanism. However, it is possible that proton gradients may affect ${ }^{36} \mathrm{Cl}^{-}$uptake by changing the membrane PD. Complete resolution of this issue will require measurements of the membrane PD during the course of ${ }^{36} \mathrm{Cl}^{-}$uptake. ${ }^{2}$

Physiologic roles of chloride transport pathways in the proximal tubule. The possibility of neutral $\mathrm{NaCl}$ transport has been previously considered in the proximal tubule. Berliner (60), Turnberg et al. (61), Liedtke and Hopfer (31, 32), and Green and Giebisch (62) have pointed out that a parallel array of $\mathrm{Na}^{+} / \mathrm{H}^{+}$and $\mathrm{Cl}^{-} /$ $\mathrm{HCO}_{3}^{-}$(or $\mathrm{OH}^{-}$) antiports could accomplish neutral $\mathrm{NaCl}$ transport. A neutral $\mathrm{NaCl}$ transport model has been proposed for the proximal tubule that uses anion exchange mechanisms in the luminal and basolateral membranes (29). Anion transport inhibitors (furosemide and a disulfonic stilbene) markedly reduced reabsorption of a sodium chloride solution in microperfusion studies of in vivo rat proximal convoluted tubules (29). The present study provides evidence consistent with an electrically neutral anion exchange mechanism or $\mathrm{HCl}$ cotransport in the luminal membrane of the rabbit proximal tubule; the stimulation of ${ }^{36} \mathrm{Cl}^{-}$uptake by an inwardly directed proton gradient is consistent with either process. This mechanism may operate in the late proximal tubule when the luminal concentrations of protons and chloride have increased with respect to the initial glomerular filtrate. The parallel operation of a $\mathrm{Na}^{+} / \mathrm{H}^{+}$antiport and a $\mathrm{Cl}^{-} / \mathrm{OH}^{-}$antiport would accomplish neutral $\mathrm{NaCl}$ transport across the luminal membrane of the proximal tubule $(29,31,32$, 49-51), and provides a role for $\mathrm{Na}^{+} / \mathrm{H}^{+}$exchange along the entire length of the proximal tubule (29). Murer,

\footnotetext{
${ }^{2}$ Preliminary studies were done to determine whether preequilibration with VAL and $80 \mathrm{mM} \mathrm{K} \mathrm{K}^{+}$"short-circuited" $\mathrm{Na}^{+}$-coupled $\mathrm{D}-\left[{ }^{3} \mathrm{H}\right]$ glucose cotransport. However, external acidity $\left(\mathrm{pH}_{0}=6.0\right)$ abolished the overshoot in $\mathrm{D}-\left[{ }^{3} \mathrm{H}\right]$ glucose uptake so this system could not be used to examine the effects of VAL and $\mathrm{K}^{+}$on electrogenic transport systems. Similar results have been reported from studies with mouse fibroblasts (18).
} 
Hopfer, and Kinne (30), Liedtke and Hopfer $(31,32)$, and Kinsella and Aronson (58) demonstrated a Na antiport in brush border vesicles prepared from intestine and kidney. This mechanism could be demonstrated in the complete absence of chloride. We believe that our results are consistent with a $\mathrm{Cl}^{-} / \mathrm{OH}^{-}$antiport (or a $\mathrm{HCl}$ symport) in renal brush border membrane vesicles prepared in the absence of sodium. Our results, and those of Liedtke and Hopfer $(31,32)$ are analogous to the counterflow effect of proton gradients on ${ }^{22} \mathrm{Na}^{+}$uptake $(30,58)$ except that the direction of the proton gradient is reversed. These observations support the thesis that transport of sodium as well as chloride may be coupled to proton gradients across the luminal membrane.

Other workers have proposed that sodium chloride is transported across the luminal membrane of the proximal tubule, intestine, rectal gland, and gallbladder as an electrically neutral ternary complex $(28,51-57)$. It is possible that this additional form of transport couples chloride entry to the sodium gradient across the luminal membrane of the proximal tubule. Our results demonstrate coupling of ${ }^{36} \mathrm{Cl}^{-}$uptake to proton gradients, but the possibility of coupling to sodium gradients has not been directly examined. It remains to be determined if ${ }^{36} \mathrm{Cl}^{-}$uptake can be directly coupled to transmembrane sodium gradients, or if the coupling is indirect and accomplished by means of the $\mathrm{Na}^{+} / \mathrm{H}^{+}$antiport. ${ }^{3}$

The electrogenic sodium transport mechanisms in the proximal tubule include sodium-coupled organic solute cotransport (1-4) and simple rheogenic sodium entry (50). Conventionally, the accompanying chloride flux has been ascribed to the paracellular shunt pathway (19-25). However, the present studies suggest the possibility of electro-diffusional transport of chloride across the luminal membrane. If the luminal membrane is relatively depolarized during electrogenic sodium-coupled cotransport, then chloride flux may proceded from lumen to cell. Once the filtered load of organic solutes is reabsorbed, chloride flux through the conductive pathway may cease, or even reverse. The latter possibility would result in a dissipative flux of chloride from the cell back into the lumen.

The direction of net electro-diffusional chloride flux out of the cell would depend upon the relative conductances of the luminal and baso-lateral mem-

${ }^{3}$ Kinsella and Aronson (58) examined the $\mathrm{Na}^{+} / \mathrm{H}^{+}$exchanger in brush border membrane vesicles prepared from rabbit renal cortex. They did not observe any effect of external chloride on ${ }^{22} \mathrm{Na}^{+}$uptake (Fig. 6 [58]). Their results do not provide any support for either model of neutral $\mathrm{NaCl}$ transport (e.g., ternary complex, or parallel exchangers). However, their studies were not done under conditions which pertain to the late proximal tubule $\left(\mathrm{pH}_{\mathrm{o}}<\mathrm{pH}_{\mathrm{i}}\right)$. branes. Electrophysiologic studies of the proximal tubule have suggested that a conductive pathway of bicarbonate, but not chloride, exists in the baso-lateral membrane $(20,63,64)$. Thus, if there is transcellular electro-diffusional flux of chloride, then an electrically neutral mechanism needs to be considered for its exchange for bicarbonate across the baso-lateral membrane (29). Recent studies of the Necturus gallbladder have suggested that chloride conductance of the basolateral membrane is low, but may increase if the cell is depolarized $(55,65)$. It is presently unknown if the anion conductance pathways in the proximal tubule are controlled or influenced by the cell membrane PD.

Reuss and Finn (66) described a chloride conductance pathway in the luminal membrane of Necturus gallbladder. Other studies have demonstrated that the intracellular chloride activity exceeds its predicted electro-chemical equilibrium value in the proximal tubule of Necturus (28), gallbladder $(51,52,54,55)$ and intestine (57). If applicable to the mammalian late proximal tubule, these findings imply that $(a)$ the chloride conductance pathway may be inactivated in the late proximal tubule once the filtered load of organic solutes (e.g., electrogenic sodium cotransport) has been reabsorbed, or $(b)$ the dissipative leak of chloride from cell to lumen may be limited if the cationic conductance of the luminal membrane is low or reduced in the absence of organic solutes. Sohtell (67) has reported that the intracellular chloride activity is at electrochemical equilibrium in the rat proximal tubule. He did not localize his impalements with respect to proximal tubule length so his results cannot be fully interpreted.

Finally, it seems likely that the overall conductance of the paracellular shunt pathway is greater than that of the transcellular route. However, the ionic gradients and electrical driving forces are very different across these pathways so a detailed, quantitative analysis would be necessary to fully assess the contribution of each pathway to transepithelial chloride conductance.

\section{ACKNOWLEDGMENTS}

We wish to thank Dr. Ulrich Hopfer, Dr. Carole M. Liedtke, and Mr. Rae Groseclose for their help with the preparation and study of brush border membrane vesicles. We are deeply grateful to Dr. Floyd C. Rector, Jr. for his generous, continuing support, interest, and suggestions. We also thank Dr. Stanley B. Prusiner and Dr. Kent C. Cochrum for the use of their equipment and facilities, and Ms. Carole Horn for her help with the manuscript.

This work was supported in part by National Institutes of Health Program Project Grant HL-06285 and National Institute of Arthritis, Metabolic and Digestive Diseases grant AM-19407. Support was also provided from the Jacobsen Fund by the Research Evaluation and Allocation Committee of the School of Medicine, University of California, San Francisco. Dr. Warnock was the recipient of a National Institute of Health Research Career Development Award (K04AM-00668) during the course of these studies. 


\section{REFERENCES}

1. Hopfer, U. 1977. Isolated membrane vesicles as tools for analysis of epithelial transport. Am. J. Physiol. 233 (Endocrinol. Metab. Gastrointest. Physiol. 2): E445E449.

2. Murer, H., and R. Kinne. 1977. Sidedness and coupling of transport processes in small intestine and renal epithelia. In Biochemistry of Membrane Transport, FEBS Symposium No. 42. G. Semenza and E. Carafoli, editors. Springer-Verlag, New York. 292-304.

3. Sacktor, B. 1977. Transport in membrane vesicles isolated from the mammalian kidney and intestine. Curr. Top. Bioenerg. 6: 39-81.

4. Ullrich, K. J. 1979. Sugar, amino acid, and $\mathrm{Na}^{+}$cotransport in the proximal tubule. Ann. Rev. Physiol. 41: 181-195.

5. Crane, R. K. 1962. Hypothesis for mechanism of intestinal active transport of sugars. Fed. Proc. 21: 891-895.

6. Schultz, S. G., and P. F. Curran. 1970. Coupled transport of sodium and organic solutes. Physiol. Rev. 50: 637-718.

7. Murer, H., and U. Hopfer. 1974. Demonstration of electrogenic $\mathrm{Na}^{+}$-dependent d-glucose transport in intestinal brush border membranes. Proc. Natl. Acad. Sci. U. S. A. 71: 484-488.

8. Aronson, P. S., and B. Sacktor. 1974. Transport of dglucose by brush border membranes isolated from the renal cortex. Biochim. Biophys. Acta. 356: 231-243.

9. Kinne, R., H. Murer, E. Kinne-Saffran, M. Thees, and G. Sachs. 1975. Sugar transport by renal plasma membrane vesicles: characterization of the systems in the brush border microvilli and basal-lateral plasma membranes. J. Membr. Biol. 21: 375-395.

10. Aronson, P. S., and B. Sacktor. 1975. The $\mathrm{Na}^{+}$gradientdependent transport of d-glucose in brush border membranes. J. Biol. Chem. 250: 6032-6039.

11. Beck, J. C., and B. Sacktor. 1975. Energetics of the $\mathrm{Na}^{+}-$ dependent transport of d-glucose in renal brush border membrane vesicles. J. Biol. Chem. 250: 8674-8680.

12. Turner, R. J., and M. Silverman. 1977. Sugar uptake into brush border vesicles from dog kidney. I. Specificity. Biochim. Biophys. Acta. 507: 305-321.

13. Lücke, H., W. Berner, H. Menge, and H. Murer. 1978. Sugar transport by brush border membrane vesicles isolated from human small intestine. Pfluegers Arch. Eur. J. Physiol. 373: 243-248.

14. Turner, R. J., and M. Silverman. 1978. Sugar uptake into brush border vesicles from dog kidney. II. Kinetics. Biochim. Biophys. Acta. 511: 470-486.

15. Beck, J. C., and B. Sacktor. 1978. The sodium electrochemical potential-mediated uphill transport of d-glucose in renal brush border membrane vesicles. J. Biol. Chem. 253: 5531-5535.

16. Beck, J. C., and B. Sacktor. 1978. Membrane potentialsensitive fluorescence changes during $\mathrm{Na}^{+}$-dependent d-glucose transport in renal brush border membrane vesicles. J. Biol. Chem. 253: 7158-7162.

17. Kessler, M., O. Acuto, C. Storelli, H. Murer, M. Muller, and G. Semenza. 1978. A modified procedure for the rapid preparation of efficiently transporting vesicles from small intestinal brush border membranes: their use in investigating some properties of d-glucose and choline transport systems. Biochim. Biophys. Acta. 506: 136- 154.

18. Lever, J. E. 1980. The use of membrane vesicles in transport studies. CRC Crit. Rev. Biochem. 8: 187-246.

19. Barratt, L. J., F. C. Rector, Jr., J. P. Kokko, and D. W. Seldin. 1974. Factors governing the transepithelial potential difference across the proximal tubule of the rat kidney. J. Clin. Invest. 53: 454-464.
20. Frömter, E. 1974. Electrophysiology and isotonic fluid absorption of proximal tubules of mammalian kidneys. MTP International Review of Science. In Kidney and Urinary Tract Physiology. Vol. 6. K. Thurau, editor. Butterworth and Co., Kent and Baltimore. 1-38.

21. Neumann, K. H., and F. C. Rector, Jr. 1976. Mechanisms of $\mathrm{NaCl}$ and water reabsorption in the proximal convoluted tubule of rat kidney. J. Clin. Invest. 58: 11101118.

22. Windhager, E. E., and G. Giebisch. 1976. Proximal sodium and fluid transport. Kidney Int. 9: 121-133.

23. Frömter, E., G. Rumrich, and K. J. Ullrich. 1973. Phenomenologic description of $\mathrm{Na}^{+}, \mathrm{Cl}^{-}$, and $\mathrm{HCO}_{3}^{-}$absorption from proximal tubules of the rat kidney. Pfluegers Arch. Eur. J. Physiol. 343: 189-220.

24. Maude, D. L. 1974. The role of bicarbonate in proximal tubular sodium chloride transport. Kidney Int. 5: 253-260.

25. Schafer, J. A., C. S. Patlak, and T. E. Andreoli. 1975. A component of fluid absorption linked to passive ion flows in the superficial pars recta. J. Gen. Physiol. 67: 445-471.

26. Maude, D. L. 1970. Mechanism of salt transport and some permeability properties of rat proximal tubule. Am. J. Physiol. 218: 1590-1595.

27. Cardinal, J., M. D. Lutz, M. B. Burg, and J. Orloff. 1975. Lack of relationship of potential difference to fluid reabsorption in the proximal renal tubule. Kidney Int. 7: $94-102$.

28. Spring, K. R., and G. Kimura. 1978. Chloride reabsorption by renal proximal tubule of Necturus. J. Membr. Biol. 38: 233-254.

29. Lucci, M. S., and D. G. Warnock. 1979. Effects of aniontransport inhibitors on $\mathrm{NaCl}$ reabsorption in the rat superficial proximal convoluted tubule. J. Clin. Invest. 64: 570-579.

30. Murer, H., U. Hopfer, and R. Kinne. 1976. Sodium/proton antiport in brush-border membrane vesicles isolated from rat small intestine and kidney. Biochem. J. 154: 587-604.

31. Liedtke, C. M., and U. Hopfer. 1977. Anion transport in brush border membranes isolated from rat small intestine. Biochem. Biophys. Res. Commun. 76: 579585.

32. Liedtke, C. M., and U. Hopfer. 1980. Chloride-sodium symport versus chloride/hydroxide antiport or chloride uniport as mechanisms for chloride transport across rat intestinal brush border membrane. Fed. Proc. 39: 734a. (Abstr.)

33. Berner, W., R. Kinne, and H. Murer. 1976. Phosphate transport into brush-border membrane vesicles isolated from rat small intestine. Biochem. J. 160: 467-474.

34. Lücke, H., G. Stange, and H. Murer. 1979. Sulphateion/sodium-ion cotransport by brush-border membrane vesicles isolated from rat kidney cortex. Biochem. J. 182: 223-229.

35. Hildmann, B., C. Storelli, W. Haase, M. Barac-Nieto, and H. Murer. 1980. Sodium ion/L-lactate co-transport in rabbit small intestinal brush-border membrane vesicles. Biochem. J. 186: 169-176.

36. Blomstedt, J. W., and P. S. Aronson. 1980. pH gradientstimulated transport of urate and p-aminohippurate in dog renal microvillus membrane vesicles. J. Clin. Invest. 65: $931-934$.

37. Schmitz, J., H. Preiser, D. Maestracci, B. K. Ghosh, J. J. Cerda, and R. K. Crane. 1973. Purification of human intestinal brush border membrane. Biochim. Biophys. Acta. 323: 98-112.

38. Booth, A. G., and A. J. Kenny. 1974. A rapid method for 
the preparation of microvilli from rabbit kidney. Biochem. J. 142, 575-581.

39. Aronson, P. S. 1978. Energy-dependence of phlorizin binding to isolated renal microvillus membranes: evidence concerning the mechanism of coupling between the electrochemical $\mathrm{Na}^{+}$gradient and sugar transport. J. Membr. Biol. 42: 81-92.

40. Berner, W., and R. Kinne. 1976. Transport of p-aminohippuric acid by plasma membrane vesicles isolated from rat kidney cortex. Pfluegers Arch. Eur. J. Physiol. 36: 269-277.

41. Evers, C., H. Murer, and R. Kinne. 1978. Effect of parathyrin on the transport properties of isolated renal brushborder vesicles. Biochem. J. 172: 49-56.

42. Evers, C., W. Haase, H. Murer, and R. Kinne. 1978. Properties of brush border vesicles isolated from rat kidney cortex by calcium precipitation. Membr. Biochem. 1: 203-220.

43. Hopfer, U., K. Nelson, T. Perroto, and K. J. Isselbacher. 1973. Glucose transport in isolated brush border membrane from rat small intestine. J. Biol. Chem. 248: 25-32.

44. Veen, H. 1974. Data processing of triple labelled liquid scintillation samples. Int. J. Appl. Radiat. Isot. 25: 355-359.

45. Lowry, O. H., N. J. Rosenbrough, A. L. Finn, and R. J. Randall. 1951. Protein measurement with the Folin phenol reagent. J. Biol. Chem. 193: 265-275.

46. Pressman, B. 1968. Ionophorous antibiotics as models for biological transport. Fed. Proc. 27: 1283-1288.

47. Henderson, P. J. F., J. O McGivan, and J. B. Chappell. 1968. The action of certain antibiotics on mitochondrial, erythrocyte and artifical phospholipid membrane: the role of induced proton permeability. Biochem. J. 111: 521-535.

48. Weiner, M. H. 1975. Mitochondrial permeability to chloride ion. Am. J. Physiol. 228: 122-126.

49. Selwyn, M. J., D. Fulton, and A. P. Dawson. 1978. Inhibition of mitochondrial anion permeability by local anesthetics. FEBS (Fed. Eur. Biochem. Soc.). Lett. 96: 148-151.

50. Schafer, J. A., S. L. Troutman, M. L. Watkins, and T. E. Andreoli. 1978. Volume absorption in the pars recta. I. "Simple" active $\mathrm{Na}^{+}$transport. Am. J. Physiol. 234 (Renal Fluid Electrolyte Physiol. 3): F332-F339.

51. Henin, S., and D. Cremaschi. 1975. Transcellular ion route in rabbit gallbladder: electrical properties of the epithelial cells. Pfluegers Arch. Eur. J. Physiol. 355: 125-139.

52. Henin, S., D. Cremaschi, G. Meyer, and G. Brivio. 1976. Cellular ion route in rabbit gallbladder epithelium. Bioelectrochem. Bioenerg. 3: 92-98.

53. Evelhoff, J., R. Kinne, E. Kinne-Saffran, H. Murer, P. Silva, F. H. Epstein, J. Stoff, and W. B. Kinter. 1978.
Coupled sodium and chloride transport into plasma membrane vesicles prepared from dogfish rectal gland. Pfluegers Arch. Eur. J. Physiol. 378: 81-92.

54. Duffey, M. E., K. Turnheim, R. A. Frizzell, and S. G Schultz. 1978. Intracellular chloride activities in rabbit gallbladder: direct evidence for the role of the sodiumgradient in energizing "uphill" chloride transport. $J$. Membr. Biol. 42: 229-246.

55. Reuss, L., and T. P. Grady. 1979. Effects of external sodium and cell membrane potential on intracellular chloride activity in gallbladder epithelium. J. Membr. Biol. 51: 15-31.

56. Nellans, H. N., and J. E. Popovitch. 1979. Chloridedependent sodium uptake by rat small intestine. Physiologist. 22: 93a. (Abstr.)

57. Duffey, M. E., S. M. Thompson, R. A. Frizzell, and S. G. Schultz. 1979. Intracellular chloride activities and active chloride absorption in the intestinal epithelium of the winter flounder. J. Membr. Biol. 50: 331-341.

58. Kinsella, J. L., and P. S. Aronson. 1980. Properties of the $\mathrm{Na}^{+}-\mathrm{H}^{+}$exchanger in renal microvillus membrane vesicles. Am. J. Physiol. 238(Renal Fluid Electrolyte Physiol. 7): F461-F469.

59. Hopfer, U., and K. Sigrist-Nelson. 1974. Intestinaltransport protein. Nature (Lond.). 252: 422.

60. Berliner, R. W. 1952. Renal secretion of potassium and hydrogen ions. Fed. Proc. 11: 695-700.

61. Turnberg, L. A., F. A. Bierberdorf, S. G. Morawski, and J. S. Fordtran. 1970. Interrelationships of chloride, bicarbonate, sodium and hydrogen transport in the human ileum. J. Clin. Invest. 49: 557-567.

62. Green, R., and G. Giebisch. 1975. Ionic requirements of proximal tubular sodium transport. II. Hydrogen ion. Am. J. Physiol. 229: 1216-1226.

63. Frömter, E., and K. Sato. 1976. Electrical events in active $\mathrm{H}^{+} / \mathrm{HCO}_{3}^{-}$transport across rat kidney proximal tubular epithelium. In Gastric Hydrogen Ion Secretion. D. Kasbekar, G. Sachs, and W. Rehm, editors. Marcel Dekker, Inc. New York. 382-403.

64. Berry, C. A., D. G. Warnock, and F. C. Rector, Jr. 1978. Ion selectivity and proximal salt reabsorption. Am. J. Physiol. 235(Renal Fluid Electrolyte Physiol. 4): F234245.

65. Reuss, L. 1979. Electrical properties of the cellular transepithelial pathway in Necturus gallbladder. III. Ionic permeability of the basolateral cell membrane. J. Membr. Biol. 47: 239-259.

66. Reuss, L., and A. L. Finn. 1975. Electrical properties of the cellular transepithelial pathway in Necturus gallbladder. II. Ionic permeability of the apical cell membrane. J. Membr. Biol. 25: 141-161.

67. Sohtell, M. 1978. Electrical chemical forces for chloride transport in the proximal tubules of the rat kidney. Acta Physiol. Scand. 103: 363-369. 